\title{
A Systematic Literature Review on Mathematical Models of Humanitarian Logistics
}

\author{
Ibrahim M. Hezam ${ }^{1,2, *(D)}$ and Moddassir k. Nayeem ${ }^{3}$ \\ 1 Statistics and Operations Research Department, College of Sciences, King Saud University, \\ Riyadh 11451, Saudi Arabia \\ 2 Department of Mathematics, Ibb University, Ibb, Yemen \\ 3 Department of Industrial and Production Engineering, American International University-Bangladesh, \\ Dhaka 1229, Bangladesh; nayeem@aiub.edu \\ * Correspondence: ialmishnanah@ksu.edu.sa
}

check for updates

Citation: Hezam, I.M.; Nayeem, M.k. A Systematic Literature Review on Mathematical Models of Humanitarian Logistics. Symmetry 2021, 13, 11. https://dx.doi.org/ 10.3390/sym13010011

Received: 4 December 2020 Accepted: 21 December 2020 Published: 23 December 2020

Publisher's Note: MDPI stays neutral with regard to jurisdictional claims in published maps and institutional affiliations.

Copyright: () 2020 by the authors. Licensee MDPI, Basel, Switzerland. This article is an open access article distributed under the terms and conditions of the Creative Commons Attribution (CC BY) license (https: / / creativecommons.org/ licenses/by/4.0/).

\begin{abstract}
Humanitarian logistics (HL) is considered one of the most significant issues of disaster operations and management. Thus, HL operation should be viable enough to function well under the uncertain and complex nature of the disaster. Many difficulties in pre-and post-disaster phases bring both human and economic losses. Therefore, it is essential to make sure that the HL operations are designed efficiently. In the last two decades, several publications have emphasized efficient HL operations and proposed several mathematical models and algorithms to increase the efficiency of HL operations and motivated the necessity of a systematic literature review. A systematic literature review is deemed pertinent due to its transparent and detailed article searching procedure. In this study, due to the importance of the mathematical optimization model, we reviewed more than one hundred articles published between 2000 and 2020 to investigate the optimization models in the field of HL. We classified the optimization models into three main problems: facility location problems, relief distribution, and mass evacuation where each of the classified areas includes both deterministic and non-deterministic models.
\end{abstract}

Keywords: humanitarian logistics; systematic literature review; facility location; relief distribution; mass evacuation

\section{Introduction}

The exponential increase in the disaster numbers has brought up myriad complications in both human life and the economic sector of a country. The number of affected people is almost proportional to the increase in disaster numbers; on average 224 million people per annum have been affected by disasters since 2006 where the economic damages were USD 154 billion in 2016, 12\% above the annual average in 2006-2015 [1]. As the impact is intensifying of disasters on the society and economical sector of a country, the improvement and the reconstruction of humanitarian logistics (HL) has become a great concern nowadays [2].

Since the Asian tsunami occurred in 2004 in the Indian Ocean, humanitarian logistics operations have become an essential area of research for academia. Before the 2004 tsunami, most of the research work considering the disaster management phases. Namely, preparation, relief, recovery, and mitigation, was studied to a smaller extent, and most of the work was in the context of supply chain and logistics. Figure 1 depicts that there were few numbers of published works before 2004 and, after 2004, the number of research work in humanitarian logistics has increased drastically. Owing to a lack of logistical expert, there were limited coordination and collaboration among humanitarian-relief-providing agencies. The lack of proper coordination and collaboration had created a blockage in the airport of the tsunami-affected countries in 2004 [3]. Due to the massive demands during a disaster, sometimes it outstrips the available resources. However, sometimes 
relief goods become excessive because many international donors send relief resources to disaster-affected countries and it results in difficulties to sort out the necessary resources and distribute them timely and cost-effectively.

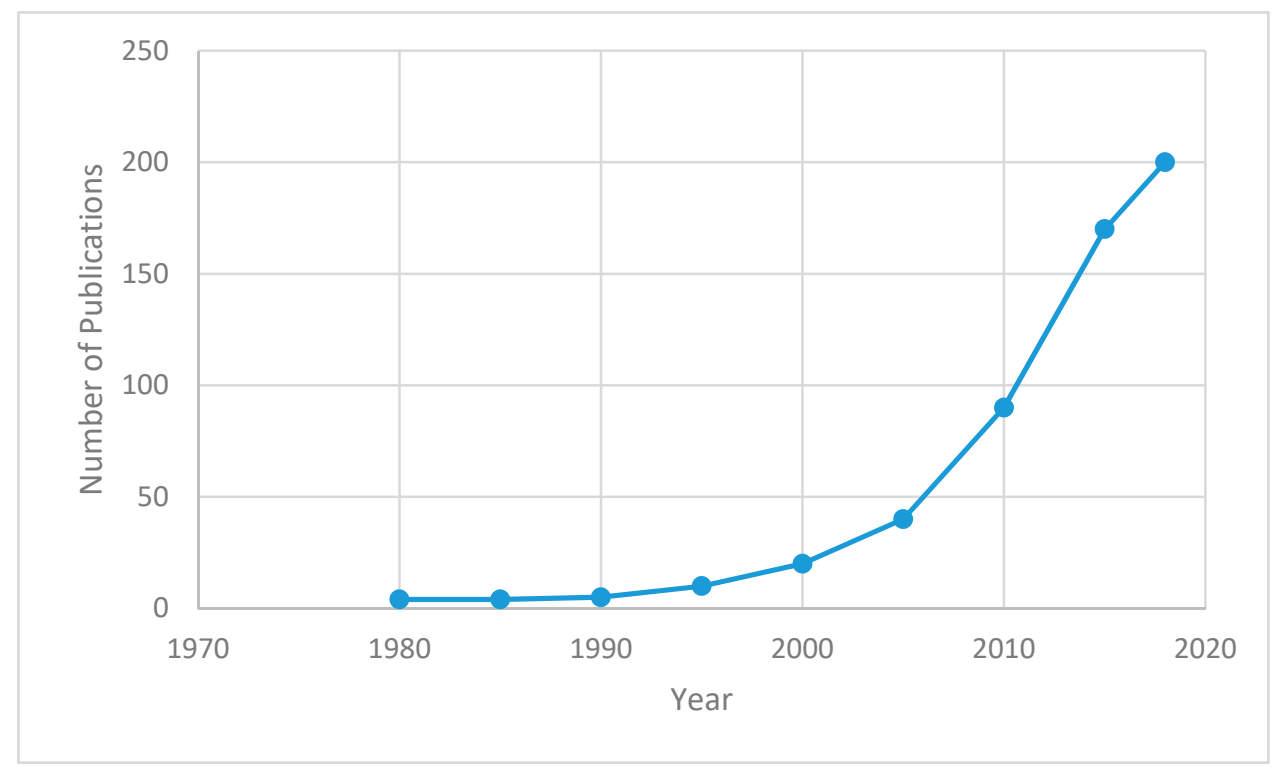

Figure 1. Number of publications by year.

Until the last decade, it was considered that natural disasters are low frequency, but in the last decade, it has been seen that the United States, China, India, the Philippines, and Indonesia are most frequently structured by natural disasters [1]. Among various natural disasters, hurricanes are one which most frequently hit the Caribbean and Central Africa. On the other hand, because of the movement and collisions of lithospheric plates, which result in "the ring of fire"- $-90 \%$ of the world's earthquakes occur along the ring of fire. Japan, the Philippines, Indonesia, and Papua New Guinea have a long history of earthquakes because of their presence in the "Ring of Fire" region [4].

Numerous studies have been published by different authors in the last decade with a different title but with the same purpose of lowering the sufferings of people in disasterstricken regions. The number of publications per year from 1980 to 2019 is depicted in Figure 1. It is discussed in the earlier paragraph that there are four stages in humanitarian operations; these are mitigation, preparedness, response, and recovery [5]. Mitigation includes the steps to reduce the vulnerability of disaster-stricken areas such as reduce the loss of life, property, and others, while the preparedness stage educates people on how to better prepare themselves to confront the disaster. Not only the people but also the preparedness stage helps the government to take proactive approaches to have a robust structure in the time of disaster. The response and recovery stages are the post-disaster phases. The response stage works to respond efficiently to minimize the loss of economic and human life while the recovery stage works to resort to the damages caused by the disaster.

In the field of HL, there are a few literature review articles published already that follow the different procedures and structures. Focusing on the disaster operation life cycle, Altay and Green [6] published a review article where they explained the required activities of the stages of the disaster. Natarajarathinam, Capar, and Narayanan [7] studied the current practices and research trends to manage the supply chain in times of crisis. Simpson and Hancock [8] reviewed the operations research technique applied in the emergency responses for the last 50 years. Caunhye, Nie, and Pokharel [9] reviewed the optimization models for emergency logistics. They have broken down the literature into three parts: facility locations, relief distribution, and causality transportation. Leiras and Adriana [10] studied the trend of HL literature by applying the systematic literature review 
process. However, the optimization model was not studied properly. On the other hand, Habib, Lee, and Memon [3] reviewed the mathematical models of the supply chain for crisis management. The authors divided the literature into three parts: facility location, network restoration, and evacuation. Bealt and Mansouri [2] discussed the literature review in the view of a collaborative aid network. They tried to find out the literature focusing on community involvement, coordination, and collaboration between different stakeholders. Boonmee, Arimura, and Asada [11] reviewed the facility location problem in HL. In their study, facility location problem is divided into four categories; one is the deterministic facility location problem, and another is the non-deterministic, which includes the stochastic and robust facility location problem and, lastly, the dynamic facility location problem. On the other hand, Ruiz [12] reviewed the literature only focusing on the relief distribution network of emergency management.

A very interesting survey on the public health system was performed by Burkle, Bradt, and Ryan [13]. The authors studied the overlooked opportunities of the public health information system and explored the current trend of it. Finally, they proposed a model for a population-based management system by a global public health database. Goldschmidt and Kumar [14] provided a literature review on the disaster management life cycle where authors covered three domains, namely, supply chain management, economics, and disaster management.

As of now the published literature review on HL focuses on a certain stage of a disaster life cycle and some modeling techniques. The literature review only focusing on mathematical modeling for the deterministic and non-deterministic models are not studied for all the four stages of the disaster. None of these published works cover the three main domains of HL and their approaches are not holistic in terms of modeling technique and solution methodologies. Therefore, this review article aims to provide a detailed study covering both the deterministic and non-deterministic models of the HL.

The rest of the paper is organized as follows: the research methodology is explained in Section 2. Section 3 provides an explanation of the published literature for the last two decades. Section 3 is further divided into subsections according to the deterministic and nondeterministic nature of the model. Finally, future directions are added in Section 4 while the conclusions are explained in Section 5.

\section{Research Methodology}

A systematic review process differentiates itself from other existing review processes by its organized and categorical approach. A systematic literature review process aims to bring out the zest from the existing published studies by following a procedure of searching, collecting, and analyzing the available resources. There are four steps for systematic review methodology; these are planning, searching, screening, and reporting [15].

Planning: The planning stage of the systematic literature helps to frame the question on which the review process starts. Normally, research questions are framed in such a way that helps to answer the current research status of a particular area and the research gap of that area. The planning stage helps to avoid the ambiguity of the review result.

Searching: The searching stage depends on the research questions addressed in the planning stage. In this literature review, we tried to collect the papers from 2000 to 2020. While searching for the papers some keywords have been used and these keywords are: "humanitarian logistics", "disaster management", "relief operations", "humanitarian relief operations", "facility locations in disaster management", "location and routing problem in HL", "commodity distribution", "relief logistics", "relief distribution and evacuation", "stochastic programming", "robust optimization", "uncertainty in disaster management", "emergency response". This searching procedure was performed with the following databases mentioned in the following Table 1. The paper collected and depicted in Figure 1 only states the optimization of HL. Only papers collected from 1980 to 2019 were considered, though we mainly concentrated on the articles that were published after 
2000. On the other hand, a few articles published in 2020 were also studied to see the recent approach to this field.

Table 1. The database search for the articles.

\begin{tabular}{ll}
\hline Database & Website \\
\hline Google Scholar & https://www.scholar.google.com \\
Science Direct & https://www.sciencedirect.com \\
Scopus & https://www.scopus.com/freelookup/form/author.uri \\
& https://www.elsevier.com/search-results?query= \\
humanitarian\%20logistics\&labels=journals & https://www.emeraldinsight.com \\
\hline
\end{tabular}

Screening: An unbiased screening process is very important for a good literature review. In this study, an intensive screening process is carried out where the inclusion and exclusion criteria are considered. This study focuses on the mathematical modeling technique in the field of HL. Thus, only those papers are included that follow the mathematical modeling technique. We did not include conference papers but peer-reviewed journal articles. Articles written from the perspective of commercial supply chain management are out of the scope of this literature review.

Reporting: In this stage, papers are divided according to the classification of HL operations. Every classified area of HL is discussed according to the nature of the model (i.e., deterministic and non-deterministic models). Finally, the current trend and the research gap are analyzed.

\section{Research in Humanitarian Logistics}

\subsection{Facility Location Problems}

In disaster management (DM), the identification of the appropriate location of shelters, medical centers, warehouses, distribution centers, debris removal sites, and others is very important to mitigate human suffering. To find the prior mentioned centers, the study of facility location problems (FLPs) in DM plays a vital role. According to Boloori Arabani and Farahani [16], FLPs can be defined depending upon two questions-which area should be selected to locate the facilities, and when should new facilities be established, or existing facilities modified? Caunhye, Nie, and Pokharel [9] reviewed most of the optimization models related to facility location problems in humanitarian logistics. The articles they reviewed include the decision of selecting new facility locations or choosing the locations among existing facilities for relief distribution, evacuation of people, and stocking the relief items before the disaster. Jia, Ordóñez, and Dessouky $[17,18]$ surveyed research articles that only include facility location models. The main challenge of the facility location problems is to find out the optimum location for facilities to minimize people's sufferings by satisfying the demand of people while keeping the associated cost minimum.

It has been found from the review of FLPs in DM that most of the articles are based on a single objective, and few papers are based on multi-objectives. From the surveyed articles, FLPs are divided into the deterministic and non-deterministic models. Deterministic and non-deterministic models of facility location problems are described in Tables 2 and 3, respectively, where the objective of each problem, constraints, decisions, stage of the disaster, solution method, and problem type are mentioned. 
Table 2. Deterministic models of the facility location problem.

\begin{tabular}{|c|c|c|c|c|c|c|}
\hline Authors & Objective Function & Constraints & Decisions & Stage of the Disaster & Solution Method & Problem Type \\
\hline Dekel et al., (2005) & $\begin{array}{l}\text { Minimize facilities for each area } \\
\text { with a given distance and } \\
\text { maximize the probability of } \\
\text { using facilities }\end{array}$ & $\begin{array}{l}\text { Identify the location of the } \\
\text { facility for each area }\end{array}$ & Location identification & Recovery & Pick-the-farthest algorithm & Set covering model \\
\hline McCall (2006) & $\begin{array}{l}\text { Minimize (victim nautical miles, } \\
\text { shortage) }\end{array}$ & $\mathrm{FC}, \mathrm{BC}$ & $\begin{array}{l}\text { Location selection, unmet } \\
\text { demand, }\end{array}$ & Preparation & GAMS/CPLEX & P-median problem \\
\hline Kongsomsaksakul et al., (2005) & $\begin{array}{l}\text { Minimize total evacuation time } \\
\text { and evacuee travel time }\end{array}$ & FC, LC, DC, TT, VC & $\begin{array}{l}\text { Shelter location selection, } \\
\text { route and destination } \\
\text { selection, }\end{array}$ & Response & GA & Location-allocation model \\
\hline Jia et al., (2007) & $\begin{array}{l}\text { Maximize the demand with } \\
\text { sufficient quantity of facility and } \\
\text { quality level }\end{array}$ & FC, FA, DC, FA & $\begin{array}{l}\text { Facility location selection, } \\
\text { number of serviced facility }\end{array}$ & Response & CPLEX & $\begin{array}{l}\text { Maximal covering, } \\
\text { p-median, p-center }\end{array}$ \\
\hline Balcik et al., (2008) & $\begin{array}{l}\text { Maximize demand coverage by } \\
\text { distribution centers }\end{array}$ & $\mathrm{IL}, \mathrm{FC}, \mathrm{BC}, \mathrm{DC}$ & $\begin{array}{l}\text { Number and location of the } \\
\text { distribution center, amount of } \\
\text { relief supplies }\end{array}$ & $\begin{array}{l}\text { Preparation and } \\
\text { response }\end{array}$ & GAMS/CPLEX & $\begin{array}{c}\text { Maximal covering location } \\
\text { model }\end{array}$ \\
\hline Rath et al., (2011) & $\begin{array}{l}\text { Minimize (depot opening cost, } \\
\text { transportation cost), maximize } \\
\text { the covered demand }\end{array}$ & FC, VC, VTT, BC, DC & $\begin{array}{l}\text { Depot identification, quantity } \\
\text { of relief item, maximum } \\
\text { operative budget, arc selection } \\
\text { for vehicle }\end{array}$ & Response & $\begin{array}{l}\text { AECA, The constraint pool } \\
\text { heuristic, CPLEX }\end{array}$ & $\begin{array}{l}\text { Set covering and vehicle } \\
\text { routing model }\end{array}$ \\
\hline Lin et al., (2012) & Minimize the operational cost & VC, FC, IL, FA & $\begin{array}{l}\text { Depot location selection, } \\
\text { number of vehicles, demand } \\
\text { point selection }\end{array}$ & Response & $\begin{array}{l}\text { A two-phase heuristic } \\
\text { approach is coded in C } \\
\text { language and interfaced } \\
\text { with ILOG CPLEX }\end{array}$ & Minimum facility location \\
\hline Abounacer et al., (2014) & $\begin{array}{l}\text { Minimize the transportation } \\
\text { duration, number of agents } \\
\text { (first-aiders) and total } \\
\text { uncovered demand }\end{array}$ & FC, VC, LC, WT & $\begin{array}{l}\text { Location selection, amount of } \\
\text { commodity to deliver }\end{array}$ & Response & $\begin{array}{l}\text { Epsilon constraint method, } \\
\text { Exact Pareto front, CPLEX }\end{array}$ & $\begin{array}{l}\text { Minimum set covering, } \\
\text { maximal covering }\end{array}$ \\
\hline Barzinpour et al., (2014) & $\begin{array}{l}\text { Maximize the cumulative } \\
\text { coverage of the population in } \\
\text { pixels of the region, minimize } \\
\text { the setup cost and } \\
\text { transportation cost }\end{array}$ & $\mathrm{MCC}, \mathrm{CTC}, \mathrm{FC}, \mathrm{IL}, \mathrm{DC}$ & $\begin{array}{l}\text { Location of shelter, allocation } \\
\text { of people, amount of } \\
\text { commodity to be transferred } \\
\text { or stored }\end{array}$ & Preparation & LINGO & Maximal covering \\
\hline Hu et al., (2014) & $\begin{array}{l}\text { Minimize (total cost of shelter, } \\
\text { total evacuation distance) }\end{array}$ & $\mathrm{FC}, \mathrm{CC}, \mathrm{ACS}$ & $\begin{array}{l}\text { Location selection, shortest } \\
\text { distance, assignment of the } \\
\text { community to shelter, } \\
\text { construction cost }\end{array}$ & Preparation & Genetic algorithm & Set covering \\
\hline Ye et al., (2015) & $\begin{array}{l}\text { Minimize the number of } \\
\text { warehouses }\end{array}$ & NWSE, LD, DSOW & $\begin{array}{l}\text { Warehouse location selection, } \\
\text { selection of open warehouse } \\
\text { for emergency operation }\end{array}$ & Preparation & VNS algorithm, CPLEX & p-center problem \\
\hline
\end{tabular}


Table 2. Cont

\begin{tabular}{|c|c|c|c|c|c|c|}
\hline Authors & Objective Function & Constraints & Decisions & Stage of the Disaster & Solution Method & Problem Type \\
\hline Khayal et al., (2015) & $\begin{array}{l}\text { Minimize logistics cost and } \\
\text { penalty cost }\end{array}$ & FC, SC, CF, DS, TT, FA & $\begin{array}{c}\text { Location of demand and } \\
\text { supply point, resource } \\
\text { allocation and transfer, } \\
\text { coverage, back ordered } \\
\text { demand }\end{array}$ & Response & CPLEX & Dynamic facility location \\
\hline Xu et al., (2016) & $\begin{array}{l}\text { Minimize the total distance, } \\
\text { maximize the coverage of all } \\
\text { shelters, maximize the shelter } \\
\text { coverage for people }\end{array}$ & FC, DPC, SRS & $\begin{array}{l}\text { Evacuation shelter site } \\
\text { selection }\end{array}$ & Response & $\begin{array}{l}\text { Lagrangian heuristic } \\
\text { algorithm and GIS }\end{array}$ & p-median and set covering \\
\hline Chen et al., (2016) & $\begin{array}{l}\text { Minimize the assignment cost of } \\
\text { facilities }\end{array}$ & FC, DS, MAF & $\begin{array}{c}\text { Temporary EMS location } \\
\text { selection }\end{array}$ & Preparation & $\begin{array}{l}\text { Reduced LR and greedy } \\
\text { algorithm, K-medoids } \\
\text { algorithm }\end{array}$ & $\begin{array}{c}\text { Capacitated facility } \\
\text { location }\end{array}$ \\
\hline Perez-Galarce et al., (2017) & $\begin{array}{l}\text { Minimization of total traveled } \\
\text { distance by the victim }\end{array}$ & CR, AM & $\begin{array}{c}\text { Number of the victim, location } \\
\text { of the refugee center }\end{array}$ & Preparation & CPLEX & $\begin{array}{l}\text { Uncapacitated facility } \\
\text { location model }\end{array}$ \\
\hline M. Akbari et al., (2017) & $\begin{array}{l}\text { Minimize total cost before and } \\
\text { after interdiction }\end{array}$ & $\mathrm{FC}, \mathrm{BC}, \mathrm{CAF}$ & $\begin{array}{l}\text { Customer assignment, location } \\
\text { of facility }\end{array}$ & Response & $\begin{array}{l}\text { Tabu search, Rainfall } \\
\text { optimization, Random } \\
\text { greedy search }\end{array}$ & $\begin{array}{c}\text { A tri-level facility location } \\
\text { r-interdiction median } \\
\text { model; }\end{array}$ \\
\hline Cotes and Cantillo et al., (2019) & $\begin{array}{l}\text { Minimize the sum of private } \\
\text { cost (transportation, inventory, } \\
\text { fixed) and deprivation cost }\end{array}$ & ADC, FC, FLC, DT, TT & $\begin{array}{l}\text { Amount of prepositioned } \\
\text { product }\end{array}$ & Preparation & GAMS/CPLEX & capacitated facility location \\
\hline Das Rubel (2018) & Maximize the coverage & NW, CLW, TOC & $\begin{array}{c}\text { Location selection of local } \\
\text { warehouse (LW) and regional } \\
\text { warehouse, coverage of LW }\end{array}$ & Response & $\begin{array}{c}\text { Open source python } \\
\text { package solver GLPK and } \\
\text { PULP }\end{array}$ & Maximal covering problem \\
\hline Tabana et al., (2017) & $\begin{array}{l}\text { Minimize the total cost of } \\
\text { procurement and preparation, } \\
\text { minimize the total relief } \\
\text { operational cost, minimize the } \\
\text { total operational relief time }\end{array}$ & $\mathrm{FC}, \mathrm{IL}, \mathrm{DC}, \mathrm{VC}, \mathrm{BC}, \mathrm{SP}$ & $\begin{array}{l}\text { Location selection, amount of } \\
\text { unused product, shortage of } \\
\text { product, inventory level }\end{array}$ & $\begin{array}{l}\text { Preparation and } \\
\text { response }\end{array}$ & NSGA-II and RPBNSGA-II & $\begin{array}{l}\text { Facility location, vehicle } \\
\text { routing, and inventory } \\
\text { management }\end{array}$ \\
\hline $\begin{array}{l}\text { Wapee Manopiniwes et al., } \\
(2020)\end{array}$ & $\begin{array}{l}\text { Minimize the amount of } \\
\text { unsatisfied demand }\end{array}$ & $\mathrm{SC}, \mathrm{VC}, \mathrm{DS}, \mathrm{NV}$ & $\begin{array}{l}\text { Amount of vehicle, amount of } \\
\text { supplies, location selection }\end{array}$ & Response & Gurobi optimizer & Location and routing \\
\hline
\end{tabular}


Table 3. Non- deterministic models of the facility location problem.

\begin{tabular}{|c|c|c|c|c|c|c|c|}
\hline Authors & Objective Function & First Stage Decisions & Second Stage Decisions & Uncertain Components & Stage of Disaster & $\begin{array}{c}\text { Solution } \\
\text { Approach/Technique }\end{array}$ & Model Type \\
\hline Chang et al., (2007) & $\begin{array}{l}\text { Minimize the expected } \\
\text { shipping distance }\end{array}$ & Location of rescue storehouse & $\begin{array}{c}\text { The number of resources to } \\
\text { be stored }\end{array}$ & Demand & Preparation & LINGO & $\begin{array}{l}\text { Two-stage stochastic } \\
\text { programming }\end{array}$ \\
\hline G. Rawls et al., (2010) & $\begin{array}{l}\text { Minimize the total expected } \\
\text { cost }\end{array}$ & $\begin{array}{l}\text { Location selection, amount of } \\
\text { pre-positioned commodity }\end{array}$ & $\begin{array}{l}\text { Distribution of available } \\
\text { supplies }\end{array}$ & $\begin{array}{c}\text { Demand and } \\
\text { transportation network } \\
\text { availability }\end{array}$ & Preparation & $\begin{array}{l}\text { LLSM algorithm, } \\
\text { CPLEX }\end{array}$ & $\begin{array}{l}\text { Two-stage stochastic } \\
\text { programming }\end{array}$ \\
\hline G. Rawls et al., (2012) & Minimize the expected cost & $\begin{array}{l}\text { Stocking quantity, location } \\
\text { selection }\end{array}$ & - & Demand & $\begin{array}{l}\text { Preparation and } \\
\text { response }\end{array}$ & CPLEX & $\begin{array}{l}\text { Stochastic } \\
\text { programming }\end{array}$ \\
\hline Murali et al., (2012) & $\begin{array}{l}\text { Maximize the number of } \\
\text { people taking medication }\end{array}$ & $\begin{array}{c}\text { Facility location selection, } \\
\text { supply to be assigned to the } \\
\text { facility, allocated supplies to } \\
\text { demand point }\end{array}$ & - & Demand & Response & $\begin{array}{l}\text { Locate-allocate } \\
\text { heuristic }\end{array}$ & $\begin{array}{l}\text { Probabilistic model } \\
\text { (CCM) }\end{array}$ \\
\hline Rennemo et al., (2014) & $\begin{array}{l}\text { Maximize the utility (in } \\
\text { terms of demand satisfaction } \\
\text { and monetary budget) }\end{array}$ & $\begin{array}{l}\text { Location selection, Number of } \\
\text { vehicle type, Amount of } \\
\text { commodity type }\end{array}$ & $\begin{array}{l}\text { Level of the residual budget, } \\
\text { amount of commodity type, } \\
\text { number of vehicle type }\end{array}$ & $\begin{array}{l}\text { Demand, the size of the } \\
\text { vehicle fleet, available } \\
\text { medical personnel and } \\
\text { state of infrastructure }\end{array}$ & Response & Xpress-IVE & $\begin{array}{c}\text { Three-stage stochastic } \\
\text { programming }\end{array}$ \\
\hline Hong et al., (2015) & $\begin{array}{l}\text { Minimize the cost of opening } \\
\text { facilities and purchasing the } \\
\text { relief supplies (1st stage) and } \\
\text { expected total cost } \\
\text { (2nd stage) }\end{array}$ & Size and location of the facility & $\begin{array}{l}\text { Amount of commodity to be } \\
\text { shipped, amount of shortage } \\
\text { and surplus, the inventory } \\
\text { level of relief supplies }\end{array}$ & $\begin{array}{c}\text { Demand and } \\
\text { transportation capacities }\end{array}$ & Preparation & $\begin{array}{l}\text { Preprocessing } \\
\text { algorithm, } \\
\text { combinatorial } \\
\text { patterns, MATLAB, } \\
\text { AMPL, CPLEX }\end{array}$ & $\begin{array}{l}\text { Two-stage stochastic } \\
\text { programming }\end{array}$ \\
\hline Renkli et al., (2015) & $\begin{array}{l}\text { Minimize the total weighted } \\
\text { distance between affected } \\
\text { areas and their assigned } \\
\text { disaster response facilities }\end{array}$ & $\begin{array}{l}\text { Location selection of } \\
\text { warehouse, amount of relief } \\
\text { item to be sent }\end{array}$ & & Amount of relief item & Preparation & CPLEX & $\begin{array}{l}\text { Probabilistic model } \\
\text { (CCM) }\end{array}$ \\
\hline Amiri et al., (2016) & $\begin{array}{l}\text { Minimize the maximum } \\
\text { amount of shortage, total } \\
\text { travel time, pre- and } \\
\text { post-disaster cost }\end{array}$ & $\begin{array}{l}\text { Location of the facility, amount } \\
\text { of commodity to transfer, } \\
\text { amount of commodity to } \\
\text { procure, inventory level, tour } \\
\text { selection }\end{array}$ & - & $\begin{array}{l}\text { Procurement cost, } \\
\text { transportation cost, } \\
\text { demand, amount of } \\
\text { stocked commodity }\end{array}$ & $\begin{array}{l}\text { Preparation and } \\
\text { response }\end{array}$ & $\begin{array}{l}\text { e-constraint method, } \\
\text { GAMS/CPLEX }\end{array}$ & $\begin{array}{c}\text { Stochastic } \\
\text { programming }\end{array}$ \\
\hline An et al., (2015) & $\begin{array}{l}\text { Minimize the total expected } \\
\text { system cost }\end{array}$ & $\begin{array}{l}\text { Location of facility, service } \\
\text { allocation }\end{array}$ & - & Disaster location & Preparation & Lagrangian relaxation & $\begin{array}{l}\text { Stochastic } \\
\text { programming }\end{array}$ \\
\hline Golabi et al., (2017) & $\begin{array}{l}\text { Minimize the aggregated } \\
\text { travel time of both people } \\
\text { and the UAVs }\end{array}$ & $\begin{array}{l}\text { Location selection, the flight } \\
\text { time, required numbers of } \\
\text { reload }\end{array}$ & - & $\begin{array}{l}\text { Demand, shortest path } \\
\text { length }\end{array}$ & Preparation & GA, MA & $\begin{array}{l}\text { Stochastic } \\
\text { programming }\end{array}$ \\
\hline
\end{tabular}


Table 3. Cont

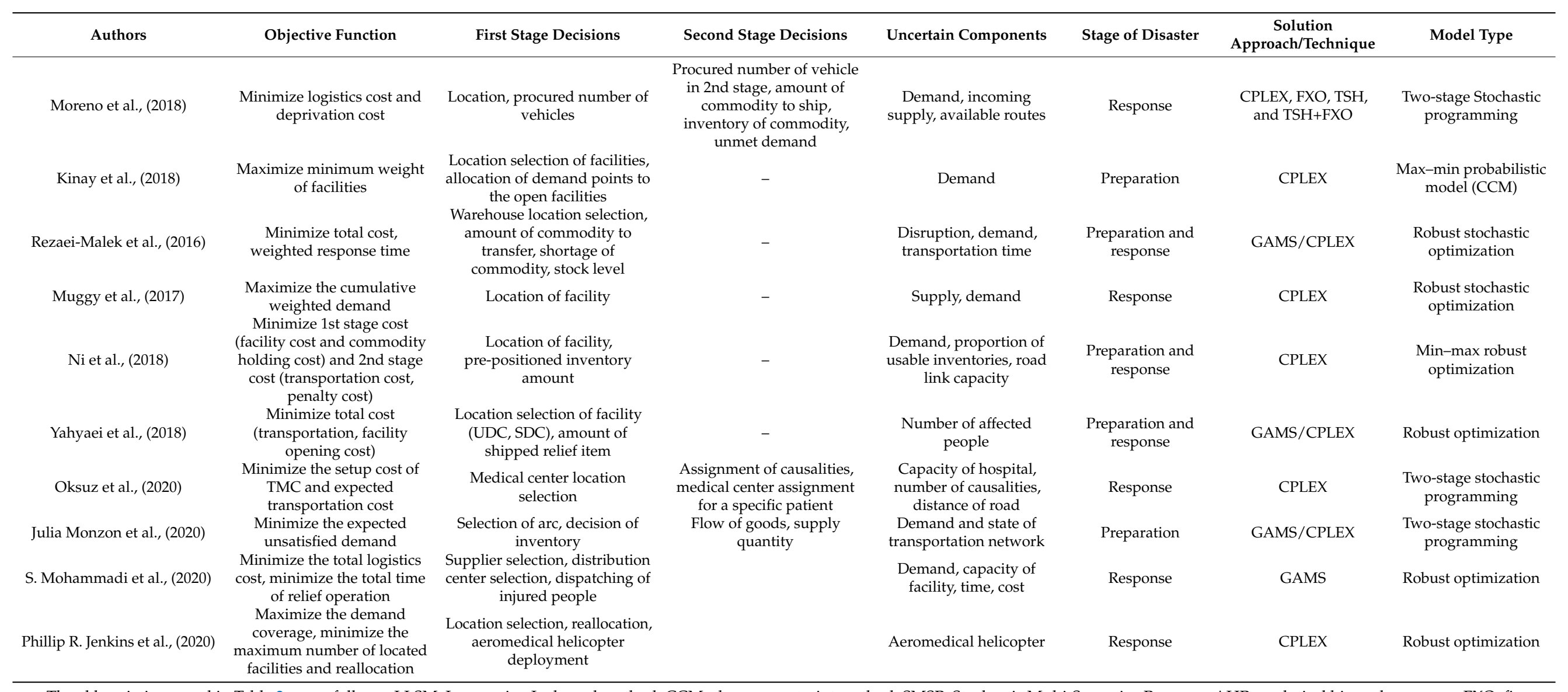

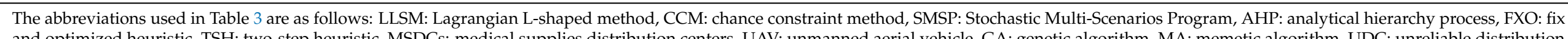

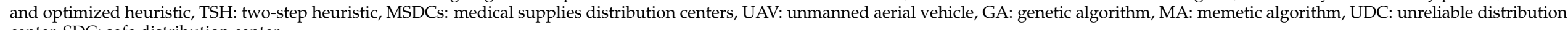
center, SDC: safe distribution center. 
McCall [22] proposed a model for the pre-disaster scenario where the author emphasized the prepositioning operation of assistance pack-up kits. This study is concerned with minimizing the shortage of relief kits and distance between affected people's location and shelter. The main decisions of this model are to locate the different types of kits at different sources, deliver kits to satisfy the demand, and whether to open stockpile or not. Lin [23] proposed a mathematical model to find out the location of temporary depots around the disaster-affected area. One of their objectives is to minimize the travel distance of the vehicle between the demand node and central depot, which is the drawback of the previous research article published by Flanigan [24]. The objective of their model is to minimize the penalty cost and transportation cost. This model is for the post-disaster scenario (response stage) while considering the constraints of the facility (depot) capacity, vehicle capacity, and the relationship between depots and demand points that ensures the assignment of demand points only to the selected depot. To deal with the multi-objective or multi-criteria model, considering the median problem, Abounacer, Rekik, and Renaud [25] proposed a multi-objective to determine the location of relief distribution centers and a transportation plan for distributing the relief. As a solution method, the author used the epsilon-constraint method due to the multi-objective model. For flood evacuation planning, a multi-level optimization model is presented in [26]. The authors divided their problem into an upper-level problem and a lower level problem. In the upper-level problem, minimization of total evacuation time is addressed, and choosing the shelter and the route for evacuee is addressed in the lower level problem. The lower level problem is focused on two issues-distribution and assignment simultaneously-where the evacuee's decision to choose the evacuation route is given preference. The main decisions of this model were to select the shelter locations and the routes.

\section{Covering Problem}

In covering problems, according to Boloori Arabani and Farahani [16], a coverage distance is followed between each demand node and the facility where each demand node will be served by each facility. Normally covering problems are suitable for the facility location problems where it is necessary to find out the location of hospitals, fire stations, and shelter sites. Covering problems can be classified into the set covering and maximal covering problems.

\section{a. Set Covering Problem}

The objective of the set covering problem is to minimize the total number of facilities while satisfying all the demand points. It also deals with location selection and minimization of the fixed cost of open facilities. The formulation of the set covering the problem proposed by Toregas [27] is as follows:

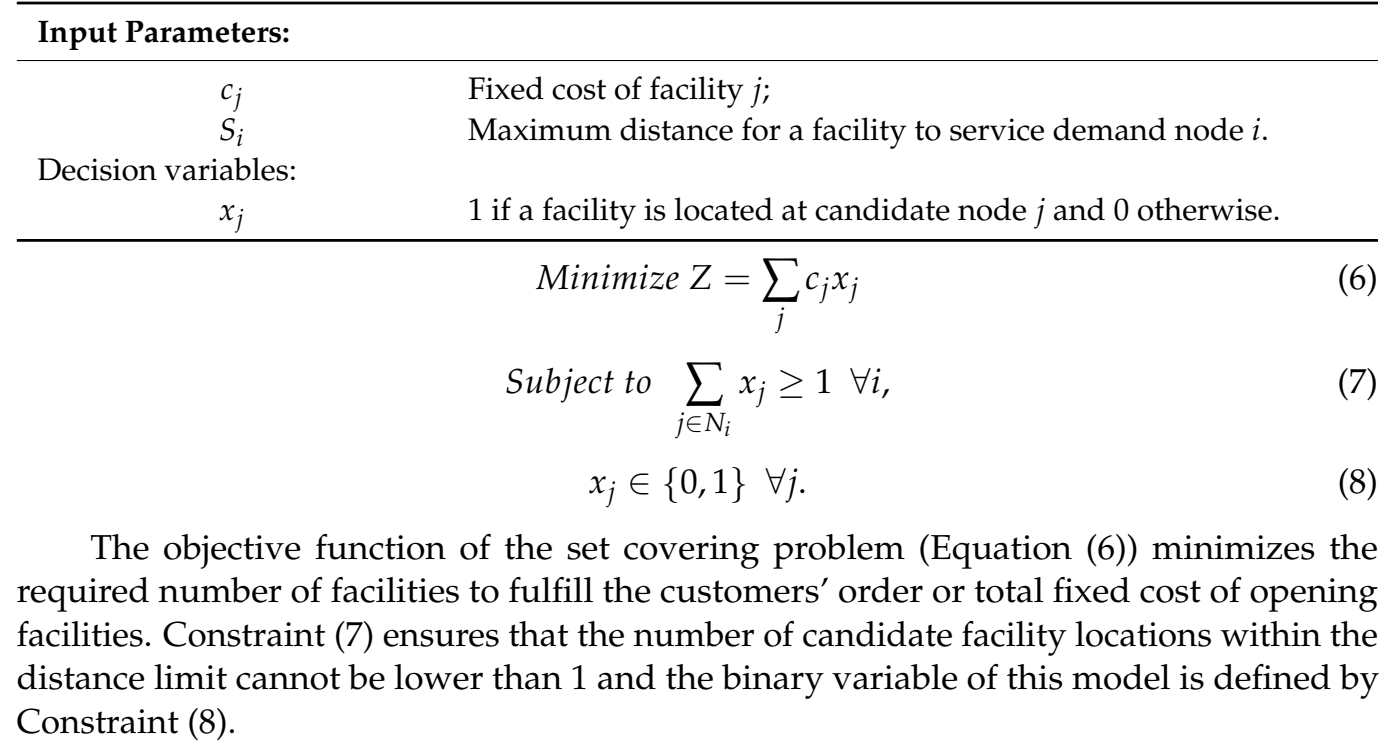


In humanitarian logistics, the first model on the set covering problem to minimize the total number of facilities needed to cover all demand points is presented in [27]. For the medical center location problem, Dekle [28] proposed a set covering model to minimize the facilities for each area with a given distance. The authors used the covering location model to identify the potential location of disaster recovery centers (DRCs) with a two-stage approach, where the stage- 1 approach gave three idealized DRC locations requiring each residence in the county to be within 20 miles of the closest DRC, and the stage- 2 approach was used to refine the approximate solution from stage- 1 . The main decision was to identify the location of the facility for each area and, as a solution method, the authors used the pick-the-farthest (PTF) algorithm. For the warehouse location and routing problem, a multi-objective optimization model was adopted by Rath and Gutjahr [29] that had three objectives, one of which is a set covering problem that tried to minimize the facility opening cost. Apart from this objective function, other objective functions are related to minimizing transportation costs and maximizing demand coverage. The model decides to select open depot, shipped quantity from the plant to the depot, maximum operative budget, and selecting the arc to use on a tour of a vehicle. Two solution methods were proposed in this problem. The first approach is an exact method to solve the small instances and the second one is a math-heuristic technique, which is named as constraint pool heuristic. Both in the exact and the heuristic method, the authors used the adaptive epsilon-constraint algorithm (AECA). On the other hand, $\mathrm{Hu}, \mathrm{Yang}$, and $\mathrm{Xu}$ [30] proposed a multi-objective optimization model for the selection of the shelter location after an earthquake that is aimed to minimize the total evacuation travel distance and total cost of the facility. Between two objectives, the second objective is the set covering problem where the facility (shelter) capacity and safety service area contiguity constraint satisfaction (separation of the service area into several parts should be avoided to decrease the chaos among evacuees) are considered. Finally, the authors proposed a non-dominated sorting genetic algorithm as one of the multi-objective evolutionary algorithms to solve their model.

According to $\mathrm{Xu}$ [31], the existing studies of facility location problems are not suitable enough for the response stage of the HL, particularly for an earthquake due to avoiding the perspective of urban planning. To overcome this overlooked problem of the facility location model, the authors studied seven principles for locating earthquake evacuation shelters, and, following these principles, they proposed a multi-criteria constraint location model. The model is derived from a $p$-median model and a location set covering model where objectives are to minimize the total distance, maximize the coverage of all shelters, and maximize the shelter coverage of people. The second objective is related to the set covering problem where the authors tried to optimize the number of shelters to save government investment. The main decision of this model is to select the evacuation shelter location, and the model is solved by the Lagrangian heuristic algorithm.

\section{b. Maximal Covering Problem}

According to R. Church and ReVelle [32], the maximal covering problem search for $p$ facilities that can serve the maximum population within a stated service distance or time given a limited number of facilities. The mathematical formulation of this problem is stated as follows:

\section{Decision Variables:}

1 if demand node $i$ is covered by a facility within distance $S$, otherwise 0 . Note that $S$ indicates the distance limit.

$$
\begin{gathered}
\text { Minimize } Z=\sum_{i} w_{i} z_{i} \\
\text { Subject to } z_{i}-\sum_{j \in N_{i}} x_{j} \leq 0 \quad \forall i, \\
\sum_{j \in N_{i}} x_{j}=p
\end{gathered}
$$




$$
x_{j}, z_{j} \in\{0,1\} \forall j .
$$

The objective is to maximize the number of covered demand nodes within the distance limitations. Constraint (10) ensures that if there is no facility at one of the candidate locations serving the node, demand node $i$ can not be covered while Constraint (11) states that in the eligible facility location there can be $p$ facilities and Constraint (12) is the binary variable of this model.

Jia, Ordóñez, and Dessouky [17] analyzed the large-scale emergencies and proposed facility location model and their model can be used as a maximal covering model, a $p$ median model or a $p$-center model according to different needs in large-scale emergencies. The objective of this model is to maximize the demand with a sufficient quantity of facility and quantity level. Balcik and Benita M. Beamon [33] proposed a maximal covering model to determine the location and the number of a distribution center for the convenience of relief distribution. The amount of relief supplies to be stored at each distribution center to meet the necessity of people affected by disasters can also be determined. The objective of their model is to maximize the coverage of demand from the established distribution center. In their model, they emphasized the inventory level of commodities in the distribution center, the capacity of the distribution center, and consideration of budget for establishing the distribution center.

Barzinpour and Esmaeili [34] proposed a multi-objective model for the preparation phase of disaster management to determine the emergency shelter location, allocate the affected people to shelter, increase the total coverage of people of a specific region, store the commodities in the facility and transfer to the demand points. This multi-objective model consists of three objectives-maximize the cumulative coverage of the population in pixels of the region, minimize the total facility setup cost, minimize the transportation cost, equipment holding cost, and shortage cost. As it is a multi-objective model, the authors used a goal programming approach to prioritize the objectives and used optimization software, LINGO, to solve this model. Das [35] studied the importance of integrating the disaster preparedness and response task. According to their study, the demand for relief items is a key factor in disaster preparedness and they identified seven influencing factors of the demand for relief items. They considered the maximal covering problem where their objective is to maximize the coverage of the local warehouse and to minimize the distribution cost.

\section{P-Centre Problem}

A $p$-center is a minimax facility location problem that consists of a set of $p$ points that minimizes the maximum distance between a demand point and the closest point belonging to that set. In humanitarian logistics, the $p$-center problem can be applied for planning the location of the hospital, fire station, shelter, and other facilities. Mark S. Daskin [36] proposed the mixed integer programming (MIP) formulation for the discrete $p$-center problem. Before Mark S. Daskin [36] proposed the MIP formulation, C.S. ReVelle, Eiselt, and Daskin [20] proposed a vertex p-center problem, where locations are allowed to serve as a node of a network. According to S.L. Hakimi [37] the $p$ center model is as follows:

\begin{tabular}{cc}
\hline Decision Variables: & \\
\hline$D$ & The maximum distance between a selected location and a demand point. \\
\hline
\end{tabular}

\section{Minimize $D$}

$$
\text { Subject to } \sum_{J} d_{i j} y_{i j} \leq D \quad \forall i \text {, }
$$

The objective function in Equation (13) will minimize the maximum distance between a selected location and a demand node. In addition, other constraints of this model are considered, such as Constraints (2)-(5) with two decision variables $\left(x_{j}, y_{i j}\right)$ from the section of the median problem. 
Ye. F [38] proposes a $p$-center model for an emergency warehouse location problem (EWLP). The main aim of this model is to determine the location of the warehouse that would be assigned to the demand points and be operated during the emergency relief distribution operation to minimize the number of the warehouse. The considered constraints ensure that the number of the warehouse will be sufficient to supply emergency materials, and the longest distance (longest distance should be less than the distance limit) will also be covered from the warehouse. The (variable neighborhood search) VNS algorithm is used to solve the problem as it a non-linear problem. Also, an optimization software CPLEX is used to solve some part of the model.

\section{Other Models on FLPs}

In addition to the three main categories of the facility location problem, there are some other categories such as the dynamic facility location problem, uncapacitated facility location, and capacitated facility location problem. Khayal [39] proposed the model for a temporary facility location, which is a dynamic facility location model. The objective of this model is to minimize the logistics and penalty cost to determine the temporary distribution center (TDC) location, the location of supply points, and resource allocation quantity. The facility capacity (FC), supply capacity (SC), commodity flow (CF), and demand satisfaction (DS) are considered as constraints and solved the model using optimization software, CPLEX. Under the dynamic facility location problem, Wapee Manopiniwes and Tabana both integrated the location problem with the routing problem which is seldomly seen in the location problem. For the capacitated facility location model, Chen and Yu [40] proposed an integer programming formulation to improve the effectiveness of emergency medical service (EMS). To enhance the post-disaster medical service operation, planning for emergency medical service Service (EMS) is important. Due to this importance, the authors determined the temporary locations for on-post EMS facilities by applying network-based partitioning in their model. The reduced Lagrangian relaxation, greedy algorithm, and K-medoids algorithm were used as a solution method. On the other hand, Cotes and Cantillo [41] proposed a model of capacitated facility location, attempting to minimize the global social costs which are the sum of both private costs (cost of transportation, inventory costs, fixed cost of facilities) and deprivation costs, determining the amount per type of product to be prepositioned for serving the areas affected by a disaster. This model was solved in GAMS using the CPLEX solver. Pérez-Galarce and Akbari-Jafarabadi [42,43] proposed the un-capacited and r-interdiction median problem, respectively, where their objective is to minimize the total travel distance by the victim and minimize total cost before and after the interdiction, respectively. Pérez-Galarce [42] proposed their model for locating and assigning the refuge centers to provide shelter, medical and psychological assistance to the victims, and the objective of this model is to minimize the total distance traveled by victims. On the contrary, Akbari-Jafarabadi [43] proposed a model of manmade disaster, while they focussed on reducing the effect on system loss (linkage between key facilities) brought by the intentional attack. The authors proposed a tri-level facility location r-interdiction median (TFLRIM) model intending to minimize the total cost before and after the interdiction. To get the knowledge of r-interdiction median model readers are advised to read the article written by R.L. Church, Scaparra, and Richard S. Middleton [44]. The abbreviations used in Table 2 are as follows: Solution approach: AECA: adaptive epsilon-constraint algorithm, GIS: geographic information system, GAMS: general algebraic modeling system, GA: genetic algorithm, LR: Lagrangian relaxation. Constraints: ADC: assignment of distribution center, ACS: assignment of the community to the shelter, AM: assignment of medical center to refugee, BC: budget constraint, CF: commodity flow, CTC: commodity transportation condition, CC: contiguity constraint, CAF: customer assignment to the facility, CLW: coverage of local warehouse, CR: capacity of refuge, DC: demand coverage, DS: demand satisfaction, DT: deprivation time, DPC: demand point coverage, DSOW: demand will only be satisfied by open warehouse, FA: facility assignment, FC: facility capacity, FLC: flow conservation constraint, FCP: flow conservation of 
product, IL: inventory level, LC: link capacity, LD: longest distance, MCC: maximal covering constraint, MAF: maximum allowed facility, NV: number of vehicle, NWSE: number of warehouse to supply emergency material, NW: number of warehouse to establish, SC: supply capacity, SP: shortage of product, SRS: service range of shelter, TT: travel time, TOC: transportation operating constraint, VC: vehicle capacity, WT: working time.

\subsubsection{Non-Deterministic Models}

Two approaches, namely, stochastic optimization and robust optimization are mostly studied for the non-deterministic model in the facility location problems. Besides these twooptimization models, there are a few other approaches to deal with uncertain parameters. The uncertain parameters in facility location problems, which are mostly seen in HL, are listed in Table 3. The detailed review of these non-deterministic models in the facility location problem is as follows:

\section{Stochastic Programming Approach}

In stochastic optimization, uncertain parameters are dispensed to a probability distribution, and parameters are usually modeled through a set of discrete scenarios with known probabilities. Most of the articles use the two-stage stochastic programming approach and very few articles are using a single-stage or three-stage stochastic programming approach. For example, Chang, Tseng, and Chen [45] proposed a two-stage stochastic programming model for flood emergency logistics to determine the location of rescue storehouses, allocation of rescue resources, considering the demand uncertainty. The two objectives of this model are minimizing the expected shipping distance of rescue equipment and minimizing the cost (sum of the facility set up cost and the average cost of all rescue equipment). The location of the rescue demand point and the quantity of rescue equipment for different flooding scenarios were estimated by the GIS analysis function and the model was solved by LINGO. Similarly, Rawls and Turnquist [46] proposed a model for prepositioning the emergency supplies and also the location to preposition. This stochastic mixed integer-programming model provides a robust model that considers the demand uncertainty as well as uncertainty regarding the transportation network availability after a natural disaster such as hurricanes. Another study for the location selection of temporary medical centers was performed by Oksuz and Satoglu [47]. They proposed a two-stage stochastic programming approach to minimize the transportation cost and set-up cost of temporary medical centers. Rawls and Turnquist [48] proposed a prepositioning plan for short-term planning considering the demand as an uncertain component. Their objective is to minimize the cost and the considered constraints are facility capacity and some requirements and bounds such as restriction on shipping extra material to minimize the holding cost on unused stocks, limitation on the number of open facilities, and limitation on stocking quantity at the shelters. A case study was analyzed using this model for meeting the demands of consumable and non-consumable goods in shelters for hurricane events that affect coastal North Carolina. Finally, the authors solved their model using CPLEX. In most cases, after the large-scale disaster the condition of transportation network becomes inaccessible and, realizing this problem, Monzón and Liberatore [49] proposed a two-stage stochastic programming model where the unavailability of the transportation network is considered.

To make sure the network reliability is at a certain level, Hong, Lejeune, and Noyan [50] introduced a risk-averse stochastic programming approach for pre-disaster relief network design with the determination of the size and location of response facilities and the inventory level of relief supplies at each facility. At the first stage of this stochastic model, the objective is to minimize the sum of the cost of opening facilities and purchasing the relief supplies, and the objective of the second stage is to minimize the expected total cost while ensuring the facility capacity for prepositioning the commodity, facility location at each node. As a solution method, the authors used the preprocessing algorithm and combinatorial patterns to formulate their proposed model as an MIP model and are implemented in 
MATLAB, AMPL, and CPLEX. On the contrary, Bozorgi-Amiri and Khorsi [51] proposed a multi-objective dynamic stochastic programming model to integrate strategic, tactical, and operational decisions. Apprehending the relationship between the location of facilities, the allocation of suppliers, vehicles, and customers with the facilities, the authors proposed this model, intending to minimize the maximum amount of shortage among the relief commodity in all periods, the total travel time, and the sum of pre and post-disaster cost. The uncertain component of this model is the demand, cost, and travel time. The authors applied the e-constraint method to make their multi-objective model a single objective model and implemented their model in CPLEX. To respond effectively in the aftermath of a disaster, Moreno [52] proposed a model to optimize the location, transportation, and fleet sizing decisions with the aim of minimizing the expected logistics cost and human suffering cost. The author presents a two-stage stochastic programming model to hedge against the uncertainty regarding demand, incoming supply, and availability of routes. The authors devised three heuristics based on decomposition and mathematical programming techniques, namely, a fix-and-optimize heuristic (FXO), a two-step heuristic (TSH), and a hybrid heuristic (FSO + TSH). On the other hand, to enhance the emergency service reliability, An and Shi [53] proposed a scenario-based stochastic mixed-integer non-linear programming model by integrating the facility disruption risk, en-route traffic congestion, and in-facility queuing delay into an integrated facility location problem. The objective of this model is to minimize the expected system cost by considering the constraints of the traffic flow assignment to each origin and destination pair, time of emergency facility establishment (an emergency service facility should be built before assigning to a victim group), victim assignment to an emergency facility, and warehouse capacity. Finally, the authors proposed a Lagrangian Relaxation algorithm to find a near-optimum solution to their model.

\section{Robust Optimization and Other Non-Deterministic Approaches}

In robust optimization, uncertainty is handled in two ways: robust models with discrete scenarios and robust models with interval uncertainty. Mulvey [54] proposed the concept of robust optimization in 1995. They considered uncertainty via a set of discrete scenarios. Later, Bertsimas and Sim [55] proposed a robust optimization approach for parameter uncertainty. Both types of approaches to robust optimization are studied in facility location problems in HL. Rezaei-Malek [56] proposed a robust stochastic optimization modeling technique for designing a relief logistics network for the preparation and response phase of a disaster. The objective of their model is to minimize the cost in both the pre-and post-disaster phases. As their model is multi-objective, they applied the Tchbycheff metric-based approach. Those who are interested in the Tchbycheff metric-based approach are referred to the article written by Reeves and MacLeod [57]. To test the significance and efficiency of their model, they conducted a case study in Iran. Another robust stochastic optimization approach is proposed by Muggy and Heier Stamm [58] for the post-disaster health care facility location problem. To make the accessibility of people who may need to take service from health care facilities and to make the equity among people affected by disasters less negatively impacted, the authors emphasized the coordination system among facility location decisions and responding organizations of health care facility providers. They introduced a dynamic, scenario-based, robust optimization model to quantify the impact on accessibility and equity resulting from the lack of coordination in locating postdisaster healthcare service facilities. Ni, Shu, and Song [59] proposed a min-max robust model to optimize the decisions of facility location, inventory pre-positioning, and relief delivery operations. On the other hand, S. Mohammadi, and Soroush Avakh [60] proposed a model for facility location and routing of victims to the safest place where authors have considered the aftershock of earthquakes. Unlike Rezaei-Malek [56] and Muggy and Heier Stamm [58], Yahyaei and Bozorgi-Amiri [61] applied the interval uncertainty procedure to design a reliable humanitarian relief network. The authors considered the disruption scenario of distribution centers and, to support the disrupted centers, they considered 
the good sharing service from the undisrupted center. The use of aeromedical facilities after the disaster was not frequently studied until 2019. To determine the location of aeromedical facilities, the optimum number to use in a certain situation is explored by Phillip R. Jenkins [62]. Gao et al. in [63], suggested a robust mathematical model that handles large-scale evacuations. The problem was divided into two phases, the assembling site identification phase, which was formulated as a non-linear model, and the second phase, whereby scheduling and vehicle routing were solved using the genetic algorithm.

Some probabilistic models are reviewed where the authors used the chance-constrained method in their model. As pre-disaster planning, Renkli and Duran [64] emphasized reducing the arrival time of relief items to the affected areas and efficient allocation of relief items. The authors developed a mixed-integer programming model for the pre-positioning of warehouses throughout a potential area. In addition, probabilistic constraints are used to ensure the arrival of relief items within a certain time window. Kınay [65] developed a modeling framework to find out the location of the shelter under demand uncertainty. In their probabilistic model, the utilization rate of shelters and their capacity is considered as the probabilistic constraint.

\subsection{Relief Distribution}

Research in the field of the relief distribution model in humanitarian logistics has been conducted in a variety of ways and, because of this, the relief distribution model can be classified into three main domains, namely, location and network design, transportation, location, and transportation. A varied mathematical model has been formulated in humanitarian logistics with some variation in objective functions and constraints for each area of relief distribution. Usually, the constraints, which are considered for the location and network design, are capacity limit (whether or not the model or author considers the capacity limit of the facility), sourcing (sourcing indicates the supply sources are considered or not and sourcing can be single and multiple), period (single period or multi-period), commodity (single commodity or multi-commodity), resource allocation, and others. The transportation problem for relief distribution adds some more constraints such as fleet composition, vehicle capacity, depots, and transportation mode. All the constraints, objectives, decisions, and solution methods are mentioned in Tables 4 and 5. 
Table 4. Deterministic models of relief distribution.

\begin{tabular}{|c|c|c|c|c|c|c|}
\hline Authors & Objective Function & Constraints & Decisions & Stage of Disaster & $\begin{array}{c}\text { Solution } \\
\text { Approach/Technique }\end{array}$ & Problem Type \\
\hline Ozdamar et al., (2004) & $\begin{array}{l}\text { Minimize the sum of unsatisfied } \\
\text { demand }\end{array}$ & $\begin{array}{l}\text { FBC (commodity and } \\
\text { vehicle), VC }\end{array}$ & NVT, ACT, AUDN & Preparation & LRIA & $\begin{array}{l}\text { Relief distribution and } \\
\text { transportation }\end{array}$ \\
\hline Tzeng et al., (2007) & $\begin{array}{l}\text { Minimize total cost, minimize } \\
\text { travel time, maximize satisfaction }\end{array}$ & SP, SD & ACT, CLSTD & Response & LINGO & Relief distribution \\
\hline Yi et al., (2007) & $\begin{array}{l}\text { Minimize the weighted sum of } \\
\text { (unsatisfied demand and } \\
\text { unserved wounded people) }\end{array}$ & $\begin{array}{l}\text { FBC (wounded people), } \\
\text { NV, VC, VL }\end{array}$ & $\begin{array}{c}\text { ACT, NWP, AUDC, NUWP, } \\
\text { NVT }\end{array}$ & Response & ACO algorithm, CPLEX & $\begin{array}{l}\text { Multi-commodity } \\
\text { network flow }\end{array}$ \\
\hline Balcik et al., (2008) & $\begin{array}{l}\text { Minimize the sum of routing and } \\
\text { penalty cost }\end{array}$ & $\mathrm{DT}, \mathrm{VC}, \mathrm{FC}, \mathrm{DF}$ & ARS, DDS, DDR & $\begin{array}{l}\text { Preparation and } \\
\text { response }\end{array}$ & GAMS/CPLEX & $\begin{array}{l}\text { Last-mile relief } \\
\text { distribution }\end{array}$ \\
\hline Yan et al., (2008) & $\begin{array}{l}\text { Minimize the cost in emergency } \\
\text { repair network and the relief } \\
\text { distribution network }\end{array}$ & $\begin{array}{c}\text { FCC, FBC (commodity), } \\
\text { WTA, AF }\end{array}$ & Repair team, arc selection & $\begin{array}{l}\text { Mitigation and } \\
\text { response }\end{array}$ & CPLEX, ACO & $\begin{array}{l}\text { Relief distribution and } \\
\text { scheduling of } \\
\text { emergency roadway } \\
\text { repair }\end{array}$ \\
\hline Campbell et al., (2008) & $\begin{array}{l}\text { Minimize the maximum travel } \\
\text { time and minimize the average } \\
\text { arrival time }\end{array}$ & STE, VC, AT, VRD & Vehicle travel decision & Response & $\begin{array}{l}\text { Insertion heuristics and } \\
\text { improvement algorithm }\end{array}$ & $\begin{array}{l}\text { Relief distribution and } \\
\text { Vehicle routing }\end{array}$ \\
\hline Horner et al., (2010) & $\begin{array}{l}\text { Minimize the cost of distributing } \\
\text { relief goods }\end{array}$ & FA, FC, MND & $\begin{array}{c}\text { Quantity of relief item, } \\
\text { distribution center type } \\
\text { selection, affected area selection } \\
\text { for distribution center }\end{array}$ & Response & CPLEX & $\begin{array}{l}\text { Relief distribution and } \\
\text { transportation }\end{array}$ \\
\hline Vitriano et al., (2011) & $\begin{array}{l}\text { Minimize (time, cost), maximize } \\
\text { (equity, reliability) }\end{array}$ & $\begin{array}{c}\text { FBC (vehicle), NV, STE, } \\
\text { VC, BC }\end{array}$ & $\begin{array}{c}\text { Quantity of relief item, quantity } \\
\text { of a stored item, number of } \\
\text { vehicles }\end{array}$ & Response & GAMS/CPLEX & Relief distribution \\
\hline Afsar et al., (2012) & $\begin{array}{l}\text { Minimize the total amount of } \\
\text { weighted unsatisfied demand }\end{array}$ & $\begin{array}{c}\mathrm{FC}, \mathrm{VC}, \mathrm{FBC} \text { (commodity } \\
\text { and vehicle) }\end{array}$ & $\begin{array}{c}\text { Location selection, number of } \\
\text { the vehicle, amount of } \\
\text { commodity }\end{array}$ & Response & CPLEX & $\begin{array}{l}\text { Relief distribution, } \\
\text { location, and routing }\end{array}$ \\
\hline Liberatore et al., (2014) & Maximize demand satisfaction & AT, DC, AF, MRP, AR & $\begin{array}{c}\text { The flow of people passing arc, } \\
\text { the flow of people at arc, arrival } \\
\text { time }\end{array}$ & $\begin{array}{l}\text { Response and } \\
\text { recovery }\end{array}$ & GAMS/CPLEX & Relief distribution \\
\hline Sheu et al., (2014) & $\begin{array}{l}\text { Minimize (travel distance, } \\
\text { operational cost, } \\
\text { psychological cost) }\end{array}$ & $\begin{array}{c}\text { FBC (evacuee), EFC, } \\
\text { VC, FC }\end{array}$ & $\begin{array}{c}\text { Distribution center selection, } \\
\text { quantity of relief resource to } \\
\text { transfer, number of injured } \\
\text { people }\end{array}$ & Response & LINGO & $\begin{array}{l}\text { Relief distribution and } \\
\text { network design }\end{array}$ \\
\hline
\end{tabular}


Table 4. Cont.

\begin{tabular}{|c|c|c|c|c|c|c|}
\hline Authors & Objective Function & Constraints & Decisions & Stage of Disaster & $\begin{array}{c}\text { Solution } \\
\text { Approach/Technique }\end{array}$ & Problem Type \\
\hline Wang et al., (2014) & $\begin{array}{l}\text { Maximization of the maximum } \\
\text { vehicle route traveling time, } \\
\text { minimization of relief distribution } \\
\text { cost, maximization of the } \\
\text { minimum route reliability }\end{array}$ & $\mathrm{FA}, \mathrm{FC}, \mathrm{VC}, \mathrm{VAD}$ & $\begin{array}{l}\text { Location selection, node } \\
\text { selection, quantity of relief item, } \\
\text { quantity of unsatisfied demand }\end{array}$ & Response & $\begin{array}{l}\text { NSGA-II and NSDE } \\
\text { algorithm }\end{array}$ & Location and routing \\
\hline $\begin{array}{l}\text { Pradhananga et al., } \\
\qquad(2016)\end{array}$ & $\begin{array}{l}\text { Minimize pre-disaster cost and } \\
\text { expected post-disaster cost }\end{array}$ & $\begin{array}{c}\text { FC, FBC (supply point) } \\
\text { AQ }\end{array}$ & $\begin{array}{c}\text { SPS, LSCP, TQP, TQPP, QTD, IN, } \\
\text { SQ, AQDC }\end{array}$ & $\begin{array}{l}\text { Preparation and } \\
\text { response }\end{array}$ & CPLEX & $\begin{array}{l}\text { Relief distribution and } \\
\text { allocation }\end{array}$ \\
\hline $\begin{array}{l}\text { Rivera-Royero et al., } \\
\qquad(2016)\end{array}$ & $\begin{array}{l}\text { Minimize the total remaining } \\
\text { fraction of unsatisfied demand }\end{array}$ & $\mathrm{BC}, \mathrm{VC}, \mathrm{DC}, \mathrm{IL}$ & $\begin{array}{l}\text { Number of trips, number of } \\
\text { pallets, inventory of pallets, } \\
\text { remaining budget }\end{array}$ & Response & $\begin{array}{l}\text { Run and fix multi-period } \\
\text { heuristic, run and fix } \\
\text { multi-period multi-stage } \\
\text { heuristic, greedy algorithm, } \\
\text { simulated annealing }\end{array}$ & Relief distribution \\
\hline Lu et al., (2016) & $\begin{array}{c}\text { Minimize total relief distribution } \\
\text { time }\end{array}$ & FC, FCC, VC & Amount of commodity flow & Response & $\begin{array}{l}\text { C++ programming } \\
\text { language, GUROBI } 6.5\end{array}$ & Relief distribution \\
\hline Al Theeb et al., (2017) & $\begin{array}{l}\text { Minimize the quantities of } \\
\text { unsatisfied demand, unserved } \\
\text { wounded, and non-transferred } \\
\text { workers }\end{array}$ & $\begin{array}{l}\text { VT, VC, FBC (vehicle), } \\
\text { NW }\end{array}$ & $\begin{array}{l}\text { Quantity of commodity, number } \\
\text { of workers, number of evacuees }\end{array}$ & Response & $\begin{array}{l}\text { CPLEX, four-phased } \\
\text { heuristic }\end{array}$ & $\begin{array}{l}\text { Relief distribution and } \\
\text { vehicle routing }\end{array}$ \\
\hline Mollah et al., (2017) & $\begin{array}{c}\text { Minimize total cost } \\
\text { (transportation and penalty) }\end{array}$ & FC, ET, VC & $\begin{array}{l}\text { Available shelter selection, } \\
\text { number of trips }\end{array}$ & Response & CPLEX, genetic algorithm & $\begin{array}{l}\text { Shelter allocation and } \\
\text { relief distribution }\end{array}$ \\
\hline Rabta et al., (2018) & $\begin{array}{l}\text { Minimize a cost function (which } \\
\text { represents the total traveling } \\
\text { distance, total traveling time or } \\
\text { total traveling costs) }\end{array}$ & $\mathrm{DC}, \mathrm{EC}, \mathrm{PC}$ & $\begin{array}{l}\text { Number of moves by drone, } \\
\text { quantity of package to carry }\end{array}$ & Response & GAMS & $\begin{array}{l}\text { Last-mile distribution, } \\
\text { drone routing system }\end{array}$ \\
\hline Wang et al., (2018) & $\begin{array}{l}\text { Minimize the total service } \\
\text { completion time }\end{array}$ & DC, FC, FBC (arc), STE & $\begin{array}{l}\text { Service starting time, quantity of } \\
\text { relief item }\end{array}$ & Response & $\begin{array}{l}\text { ABC algorithm, the Rh } \\
\text { algorithm }\end{array}$ & $\begin{array}{l}\text { Medical team } \\
\text { assistance scheduling } \\
\text { and relief distribution }\end{array}$ \\
\hline
\end{tabular}

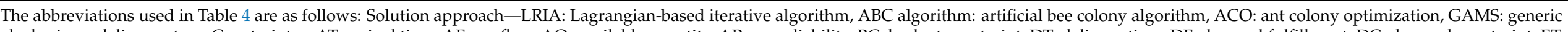

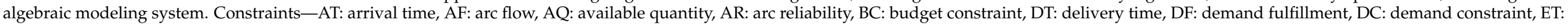

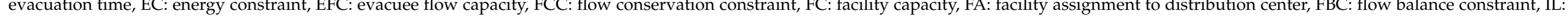

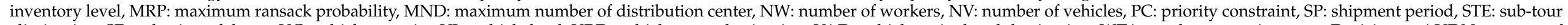

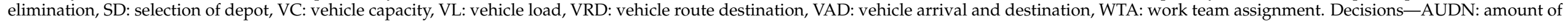

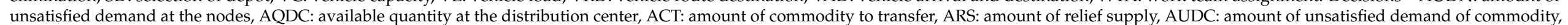

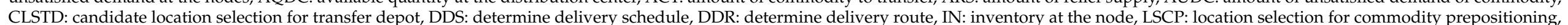

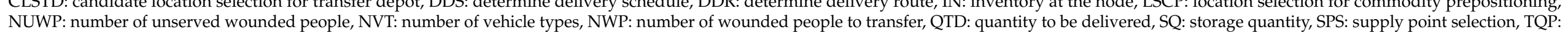
NUWP: number of unserved wounded people, NVT: number of vehicle typ
total quantity to be purchased, TQPP: total quantity to be pre-positioned. 
Table 5. Non-deterministic models of relief distribution.

\begin{tabular}{|c|c|c|c|c|c|c|}
\hline Authors & Objective Function & Uncertain Components & Stage of Disaster & $\begin{array}{c}\text { Solution } \\
\text { Technique/Approach }\end{array}$ & Model Type & Problem Type \\
\hline Barbarosoglu et al., (2004) & $\begin{array}{l}\text { Minimize the total transportation cost and } \\
\text { recourse cost }\end{array}$ & $\begin{array}{l}\text { Demand, supply, capacity } \\
\text { of vehicle }\end{array}$ & Response & GAMS/OSL & $\begin{array}{l}\text { Two-stage stochastic } \\
\text { programming }\end{array}$ & $\begin{array}{l}\text { Relief distribution and } \\
\text { transportation }\end{array}$ \\
\hline Salmeron et al., (2010) & $\begin{array}{l}\text { Minimize expected casualties, minimize } \\
\text { expected unmet transfer population }\end{array}$ & $\begin{array}{l}\text { Demand, number of relief } \\
\text { worker, travel time }\end{array}$ & Preparedness & CPLEX & $\begin{array}{l}\text { Two-stage stochastic } \\
\text { programming }\end{array}$ & $\begin{array}{l}\text { Asset prepositioning } \\
\text { and relief operations }\end{array}$ \\
\hline Mete et al., (2010) & $\begin{array}{l}\text { Minimize the total warehouse operating cost and } \\
\text { total transportation time }\end{array}$ & $\begin{array}{l}\text { Transportation time, } \\
\text { demand }\end{array}$ & Preparation & CPLEX & $\begin{array}{l}\text { Two-stage stochastic } \\
\text { programming }\end{array}$ & $\begin{array}{l}\text { Location-routing and } \\
\text { relief distribution }\end{array}$ \\
\hline Doyen et al., (2012) & $\begin{array}{l}\text { Minimize the total cost (transportation, facility } \\
\text { establishment, inventory holding, the penalty } \\
\text { for shortage) }\end{array}$ & $\begin{array}{c}\text { Capacity, unit } \\
\text { transportation cost, } \\
\text { demand, transportation } \\
\text { time }\end{array}$ & $\begin{array}{l}\text { Preparedness and } \\
\text { response }\end{array}$ & $\begin{array}{l}\text { Lagrangean } \\
\text { relaxation-based } \\
\text { heuristics, CPLEX }\end{array}$ & $\begin{array}{l}\text { Two-stage stochastic } \\
\text { programming }\end{array}$ & $\begin{array}{l}\text { Location and } \\
\text { distribution (network } \\
\text { design) }\end{array}$ \\
\hline Li et al., (2011) & $\begin{array}{l}\text { Minimize total cost (fixed cost of operating } \\
\text { shelters, inventory cost) and total } \\
\text { transportation cost }\end{array}$ & $\begin{array}{l}\text { Evacuees number, } \\
\text { transportation cost, the } \\
\text { operational cost of one } \\
\text { evacuee }\end{array}$ & $\begin{array}{l}\text { Preparedness and } \\
\text { response }\end{array}$ & CPLEX & $\begin{array}{l}\text { Two-stage stochastic } \\
\text { programming }\end{array}$ & $\begin{array}{l}\text { Location and } \\
\text { distribution (network } \\
\text { design) }\end{array}$ \\
\hline Noyan et al., (2015) & Maximize the expected total accessibility & $\begin{array}{l}\text { Demand, transportation } \\
\text { network }\end{array}$ & Response & $\begin{array}{l}\text { Branch and cut } \\
\text { algorithm }\end{array}$ & $\begin{array}{l}\text { Two-stage stochastic } \\
\text { programming }\end{array}$ & $\begin{array}{l}\text { Last mile relief } \\
\text { distribution model } \\
\text { (network) }\end{array}$ \\
\hline Tofigi et al., (2016) & $\begin{array}{l}\text { Minimize the total cost (warehouse and } \\
\text { distribution center operating, inventory), } \\
\text { distribution time, maximum weighted } \\
\text { travel time }\end{array}$ & $\begin{array}{l}\text { Supply, demand, road } \\
\text { availability }\end{array}$ & $\begin{array}{l}\text { Preparedness and } \\
\text { response }\end{array}$ & DEA & $\begin{array}{l}\text { Two-stage stochastic } \\
\text { programming }\end{array}$ & $\begin{array}{l}\text { Relief distribution } \\
\text { (network) }\end{array}$ \\
\hline Ahmadi et al., (2015) & $\begin{array}{l}\text { Minimize the total distribution time, penalty cost } \\
\text { of unsatisfied demand and fixed cost of } \\
\text { opening DC }\end{array}$ & Road destruction, location & Response & $\begin{array}{l}\text { GAMS, Neighborhood } \\
\text { search algorithm }\end{array}$ & $\begin{array}{l}\text { Two-stage stochastic } \\
\text { programming }\end{array}$ & $\begin{array}{l}\text { Location-routing and } \\
\text { last mile relief } \\
\text { distribution }\end{array}$ \\
\hline Moreno et al., (2015) & $\begin{array}{l}\text { Minimize the total expected cost (opening and } \\
\text { operating relief center, vehicle assignment, } \\
\text { transportation, inventory, unmet demand, } \\
\text { demand satisfaction) }\end{array}$ & $\begin{array}{l}\text { Demand, supply, inventory, } \\
\text { road availability }\end{array}$ & Response & $\begin{array}{l}\text { Relax-and-fix } \\
\text { heuristics, } \\
\text { Fix-and-optimize } \\
\text { heuristics }\end{array}$ & $\begin{array}{l}\text { Stochastic } \\
\text { programming }\end{array}$ & $\begin{array}{l}\text { Location and } \\
\text { transportation }\end{array}$ \\
\hline Alem et al., (2016) & $\begin{array}{l}\text { Minimize the cost of stock prepositioning, } \\
\text { vehicle hiring, inventory, and unmet demand }\end{array}$ & Demand, supply, budget & Preparedness & Two-phase heuristic & $\begin{array}{l}\text { Two-stage stochastic } \\
\text { programming }\end{array}$ & $\begin{array}{l}\text { Relief distribution } \\
\text { (network) }\end{array}$ \\
\hline Zheng et al., (2013) & $\begin{array}{l}\text { Minimize total time delay, total transportation } \\
\text { cost, and total transportation risk }\end{array}$ & $\begin{array}{l}\text { Quantity of good, cost, } \\
\text { arrival time, travel time }\end{array}$ & Preparation & MOTS, MOGA & Fuzzy optimization & $\begin{array}{c}\text { Transportation planning } \\
\text { and relief distribution }\end{array}$ \\
\hline
\end{tabular}


Table 5. Cont.

\begin{tabular}{|c|c|c|c|c|c|c|}
\hline Authors & Objective Function & Uncertain Components & Stage of Disaster & $\begin{array}{c}\text { Solution } \\
\text { Technique/Approach }\end{array}$ & Model Type & Problem Type \\
\hline Najafi et al., (2013) & $\begin{array}{l}\text { (a) Minimize the total weighted unserved } \\
\text { injured people } \\
\text { (b) Minimize the total weighted unsatisfied } \\
\text { demand } \\
\text { (c) Minimize the total number of vehicles } \\
\text { utilized in response }\end{array}$ & $\begin{array}{l}\text { Demand, number of } \\
\text { injured people, supply of } \\
\text { the commodity }\end{array}$ & Response & CPLEX & $\begin{array}{l}\text { Robust optimization, } \\
\text { stochastic model }\end{array}$ & $\begin{array}{l}\text { Transportation and } \\
\text { relief distribution }\end{array}$ \\
\hline Fereidumi et al., (2017) & Minimize the total cost & $\begin{array}{l}\text { Demand, rescue operation } \\
\text { time, transportation cost, } \\
\text { operational cost }\end{array}$ & $\begin{array}{l}\text { Preparedness and } \\
\text { response }\end{array}$ & GAMS & Robust optimization & $\begin{array}{l}\text { Distribution and } \\
\text { evacuation }\end{array}$ \\
\hline Hagi et al., (2017) & $\begin{array}{l}\text { (a) Minimize the total cost (facility } \\
\text { establishment, commodity procurement, } \\
\text { transportation, shortage, inventory holding) } \\
\text { (b) Maximize the satisfaction level by } \\
\text { minimizing the maximum shortage } \\
\text { (c) Minimize the cost of health center } \\
\text { establishment, casualty transportation } \\
\text { (d) Maximize the satisfaction level by } \\
\text { minimizing the sum of maximum neglected } \\
\text { casualties }\end{array}$ & Demand, supply, and cost & $\begin{array}{l}\text { Preparedness and } \\
\text { response }\end{array}$ & MOGSA & $\begin{array}{l}\text { Robust stochastic } \\
\text { optimization }\end{array}$ & $\begin{array}{l}\text { Location and } \\
\text { distribution }\end{array}$ \\
\hline Vahdani et al., (2018) & $\begin{array}{l}\text { (a) Minimize the cost (facility establishment, } \\
\text { storing goods in facilities) } \\
\text { (b) Minimize the vehicle travel cost } \\
\text { (c) Minimize the vehicle travel time } \\
\text { (d) Maximize the route reliability }\end{array}$ & Storage capacity & Response & NSGAII and MOPSO & Robust optimization & $\begin{array}{l}\text { Location, routing, and } \\
\text { distribution }\end{array}$ \\
\hline Yuchen Li et al., (2020) & $\begin{array}{l}\text { Minimize the fixed cost of opened supply } \\
\text { facilities, and the cost of prepositioned relief } \\
\text { goods }\end{array}$ & $\begin{array}{l}\text { Demand, transportation } \\
\text { time }\end{array}$ & $\begin{array}{l}\text { Preparation and } \\
\text { response }\end{array}$ & CPLEX, MATLAB & $\begin{array}{l}\text { Three stage stochastic } \\
\text { programming }\end{array}$ & $\begin{array}{l}\text { Distribution and } \\
\text { location }\end{array}$ \\
\hline Peiman Ghasemi1 et al., (2020) & $\begin{array}{l}\text { (a) Minimize the untreated injured people } \\
\text { (b) Minimize the shortage of commodities }\end{array}$ & Demand & $\begin{array}{l}\text { Preparation and } \\
\text { response }\end{array}$ & NSGAII & $\begin{array}{l}\text { Two-stage stochastic } \\
\text { programming }\end{array}$ & $\begin{array}{l}\text { Distribution and } \\
\text { evacuation }\end{array}$ \\
\hline
\end{tabular}

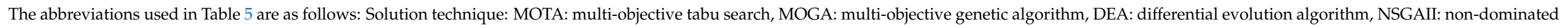
sorting genetic algorithm II, MOPSO: multi-objective particle swarm optimization. 


\subsubsection{Deterministic Models}

As the relief distribution models diversify in many ways, the effort has been given to review every diversified section in the following Table 4 of the deterministic model. Sometimes, the relief distribution model also associates with location problems and routing problems. Afshar and Haghani [66] suggested a model that serves both location and routing problems. $\mathrm{H}$. Wang, $\mathrm{Du}$, and Ma [67] considered a multi-objective location-routing model with split delivery to facilitate the relief distribution activities. The authors take into account the travel time, the total cost, and reliability with split delivery in their proposed model. To solve the model, the authors proposed the non-dominated sorting genetic algorithm and non-dominated sorting differential evolution algorithm, and a case study was conducted on the great Sichuan Earthquake in China to validate their proposed model. The commercial solver, CPLEX, was also used to solve the model. Yi and Kumar [68] proposed a network flow problem and used a meta-heuristic called ant colony optimization (ACO) to solve the problem. This model minimizes the weighted sum of unsatisfied demand of all commodities and unserved wounded people at demand nodes and emergency units. In their model, they considered a coordination center to obtain the information for predicting future demand so that they can make a balance of the commodity flow and vehicle flow on the demand nodes. Another network flow the problem that is integrated with the vehicle routing problem is proposed by Özdamar, Ekinci, and Küçükyazici [69]. They decomposed the model into two multi-commodity network flow problems; the first one is for transporting commodities and the second one is for vehicle flows. The objective of this model is to minimize the sum of the unsatisfied demand of all commodities with the determination of the number of vehicles to be used for transportation, the amount of the commodity to be transferred, and the amount of unsatisfied demand of a commodity at a specific node. The authors proposed a Lagrangean relaxation-based iterative algorithm to solve their model. On the other hand, Campbell, Vandenbussche, Hermann, and Al Theeb and Murray [70,71], did not integrate the vehicle routing problem with location problems. They only considered the vehicle routing problem for relief distribution. Campbell, Vandenbussche, and Hermann [70] developed a model by considering two objective functions for the classical traveling salesman problem (TSP) and the vehicle routing problem (VRP). The objective of this TSP is to minimize the maximum arrival time (minmax routing) and the objective of VRP is to minimize the average arrival time (minavg routing). The sub tour elimination (STE-for a given set of nodes, a TSP sub tour may be visiting some nodes among a given set of nodes and this sub tour is not the feasible solution so it must be eliminated), customer visit by vehicle and vehicle capacity are considered in the constraints. The authors proposed the insertion heuristic and improvement algorithm to solve their model. Al Theeb and Murray [71] considered a vehicle routing problem to minimize the quantities of unsatisfied demand, unserved wounded and non-transferred workers while distributing the relief commodities in the post-disaster phase. The authors suggested a vehicle routing problem with split delivery to expedite the relief distribution process. The authors proposed this multi-depot, multiperiod, and multi-commodity model to determine the quantity of the commodity to pick up from the node, the number of workers to transfer from a node, the number of evacuees to pick up from a node, the quantity of the commodity to deliver, and the number of evacuees to deliver. The authors developed a four-phased heuristic to solve their problem for a large-scale instance.

After the disaster, international donations are received from different sources and to store the commodities they are transferred to central warehouses. Finally, from the central warehouses, relief goods are sorted out and sent to the regional warehouse or distribution center. The regional distribution center is the final stage from where the relief goods are dispatched to the disaster-affected areas. Due to the complexity in the final stage of relief distribution, some researchers follow the last mile distribution strategy. Balcik, Beamon, and Smilowitz [72] are some of the pioneers who developed the last mile distribution model in humanitarian logistics. In this study, they considered a vehicle based last-mile 
distribution system. Their main decisions are to allocate the relief supplies at the last-mile distribution centers and determine the delivery schedule/route for each vehicle. The objective of their mixed integer-programming model is to minimize the routing cost and penalty cost for back-ordered demand based on supply, vehicle capacity, and delivery time restrictions. Another research on last-mile distribution in HL was carried out by Rabta, Wankmüller, and Reiner [73]. Due to the destroyed roads and debris-covered areas after the disaster, aid agencies have to confront some difficulties to distribute relief goods. To overcome this problem, Rabta, Wankmüller, and Reiner [73] proposed a drone fleet model. In their drone fleet model, they used unmanned aerial vehicles (UAVs) as the drone fleet and the objective of the model is to minimize the total traveling distance (or time/cost) of the drones. As the constraints, they considered the degree constraints (a drone can visit the recharging station and depots as many times as possible, but the in-degree must be equal to out-degree), demand constraints, and energy constraints.

Horner and Downs [74] proposed a facility location model to transport and distribute the relief goods to the affected areas. This is a capacitated warehouse location model where the location decisions are taken only for the warehouse to store the commodities. The authors present a geographic information system (GIS)-based model to transport the relief goods from warehouses to people in the affected areas. The objective of their model is to minimize the costs of distributing relief goods with the determination of the location of distribution centers, the number of relief good packages to deliver. A case study was analyzed using their model for the hurricane disaster relief plan in Leon County, Florida, USA. Tzeng, Cheng, and Huang [75] constructed a multi-objective relief distribution model with three objectives: minimizing the total cost, minimizing the total travel time, and maximizing minimal satisfaction. In the constraints, the authors considered the control over shipment and insufficient shipment of goods, that goods shipped in and out of transfer depots should be on the same period, and predetermined quantities of relief goods. Vitoriano [76] proposed a decision support system to assist the organizations in charge of distributing relief goods after a disaster. The decisions that can be determined through this multi-criteria model are the number of vehicles that should travel from one node to another, and the amount of relief goods that will be sent and received to the destination node. The objective of this model is to minimize (transportation time and cost) and maximize (equity and reliability); the constraints are flow balance of vehicles, a number of operating vehicles at the node should be equal to the available number of the vehicle, sub-tour elimination, and vehicle capacity. Pradhananga [77] proposed a three-echelon network model for the distribution of emergency supplies. This model is proposed for both pre- and post-disaster planning and response operation, respectively, where the objective of the pre-disaster phase is to minimize the fixed cost of establishing facilities, purchasing emergency supplies, and the transportation cost. On the other hand, the objective of the post-disaster phase is to minimize logistics and deprivation costs. Lu, Ying, and Chen [78] proposed a real-time relief distribution model based on a rolling horizon-based framework in the aftermath of the disaster. The rolling horizon framework has two modules-one is a state estimation and prediction module, and another is a relief distribution module. In the first module, this framework will predict the relief demands and delivery time and, according to the prediction, the second module will solve the optimal relief distribution flows. The main goal of their model is to minimize the total travel time to deliver relief goods to satisfy the demand of people in need. They conduct a case study to demonstrate their model on the large-scale earthquake that occurred in Taiwan. 


\subsubsection{Non-Deterministic Models}

In search of non-deterministic models, we have found both stochastic programming and robust optimization approaches. In stochastic programming approaches, the literature is divided into the first stage and two-stage stochastic programming approaches.

\section{The Stochastic Programming Model for Relief Distribution}

Similar to the deterministic model, the non-deterministic model also covered all the possible diversified ways of relief distribution. All the reviewed papers, with their special characteristics, are mentioned in Table 5.

In emergency management, decision-makers usually make decisions about HL network design and relief distribution, confronting some uncertainties. To make the decision efficiently, researchers have studied many stochastic models. Among the HL network's decisions, the selection of facility location (i.e., location for distribution centers, temporary medical service center, and others) is one of the main decisions frequently considered by the researchers. One of the early works for a two-stage stochastic programming approach is conducted by Li, Jin, and Zhang [79]. Their stochastic model is for making decisions in both the pre-and post-disaster phases of the disaster. Their proposed model for the pre-disaster stage helps to decide the locations of facilities, capacities of facilities, and resources of new permanent shelters. On the other side, in the response stage, resources will be distributed to shelters and evacuees will be rescued to shelters. The objective of the first stage of their model is to minimize the fixed cost to have new permanent shelters, and the inventory cost of resources at the shelters, while the second stage cost is to minimize the transportation cost of evacuees, transportation cost of resource distribution, the surplus and shortage costs for resources after an evacuation. Noyan, Balcik, and Atakan [80] developed a two-stage stochastic model to determine the locations and capacities of the relief distribution points in the last-mile relief distribution networks where the uncertain elements are demand and transportation networks. The authors focused on two types of supply allocation policies and proposed the hybrid allocation policy considering their accessibility and equity. Finally, the author devised a branch-and-cut algorithm based on Benders decomposition to solve the large-scale problem. Tofighi, Torabi, and Mansouri [81] developed a two-stage scenario-based possibilistic-stochastic programming approach to design the HL network. The first stage involves selecting the location of the warehouse and distribution center where the uncertain elements are the demand, supply, and availability level of the transportation network's routes after the earthquake. In the second stage, relying on the distribution plan is required to minimize the total distribution time and the maximum weighted shortage cost of unmet demands. In this model, authors classify the relief items into the critical and non-critical item, and, in the constraint, they enforce the restrictions on the available capacity of warehouse and distribution centers for non-critical relief items. Another important constraint for their model is to consider a restriction on establishing no more than one warehouse at a candidate location. Alem, Clark, and Moreno [82] proposed a two-stage stochastic network flow model to expedite the process of distributing humanitarian aid to victims of disaster-affected areas. Some practical characteristics such as allocation of budget, procurement, varying lead-time over a dynamic multi-period horizon, and the fleet size of multi-type of vehicles are considered in this model, which are seldom considered in network flow models. Finally, the author provided a case study on the floods and landslides in the Rio de Janeiro state, Brazil. To minimize the expected number of casualties, Salmero [83] developed a two-stage stochastic programming model where the first stage decision is to expand the facilities such as warehouses, medical centers with personnel, shelters and the second stage decisions were about logistical problems.

Once the logistics network is established, the relief delivery plans are taken to transfer the relief goods to safe shelters as soon as possible. Transportation or distribution problems can make the relief delivery plan more efficient. Normally in transportation problems for distributing relief items, the demand of the commodity, the supply of the commodity, 
the capacity of the vehicle, transportation arrival time, and travel time are considered as an uncertain element. Barbarosoğlu and Arda [84] proposed a two-stage stochastic programming model for transportation planning in the disaster response phase. The main objective of their model is to minimize the total transportation cost and recourse cost. To make the model more dynamic, the authors considered multi-commodity and multi-modal transportation system in their model. Apart from the logistics network establishment, another important area of crisis management is to research routing problems along with location and relief distribution. To decide for both pre and post-disaster rescue center location and the amount of relief item to be stocked and the flow of relief item at each echelon of the HL network, Döyen, Aras, and Barbarosoğlu [85] developed a two-stage stochastic programming model. The objective of their study is to minimize the total cost of facility location, inventory holding cost, transportation, and shortage cost where the uncertain elements are facility capacity, unit transportation cost, transportation time, and the demand for relief goods. In 2010, Mete and Zabinsky [86] proposed a two-stage stochastic programming model for medical supply storage, location, and distribution. They considered the vehicle routing problem in their sub-problem to transport the medical supplies in disaster response. In the multi-modal transportation context under some uncertainties, Moreno, Alem, and Ferreira [87] proposed a two-stage stochastic programming model for multicommodity distribution. Their model is the integration of a few different decisions, namely, location decision, transportation, and fleet sizing decisions in a multi-period context. One special characteristic of this model is to reuse the vehicle within the same period to cover extra routes. Morteza, Abbas, and Behnam [88] proposed a multi-depot location routing model to facilitate the disaster relief operation. There are many studies where routing is considered with a location problem, but few studies considered the routing for last-mile distribution. Morteza, Abbas, and Behnam [88] are among those who considered the location and routing simultaneously with the last-mile distribution. The objective of this model is to minimize the total distribution time, penalty cost, and fixed costs of opening the distribution center. In an attempt to combine distribution and evacuation activities, Peiman Ghasemi and Kaveh Khalili-Damghani [89] proposed a two-stage stochastic programming approach. Their proposed model is for both pre- and post-disaster phases, where in the pre-disaster phase the authors tried to find the optimum location for the permanent relief distribution center and in the post-disaster phase, their concentration is on temporary treatment centers to facilitate the treatment of injured people. On the other hand, a threestage stochastic programming model, a unique approach to making a correlation between primary and secondary disaster is proposed by Li. Y, Yu, and Zhang [90].

\section{Robust Optimization and Others}

Measuring the exact value of the probability distribution of the uncertain parameter is sometimes difficult. In a disaster scenario, it is tough to find out the exact value of uncertain parameters. Robust optimization is suitable in such cases by employing different robust measures for uncertain parameters. In robust optimization, uncertainty is handled in two ways, namely, robust models with discrete scenarios and robust models with interval uncertainty. Most of the published papers related to the robust optimization model in the case of relief distribution problems use the interval uncertainty to represent the uncertain parameters.

Usually, when a disaster such as an earthquake occurs, relief organizations are not prepared with enough resources to meet the demand of disaster-affected areas. By addressing this problem, Najafi, Eshghi, and Dullaert [91] proposed a robust optimization model to distribute scarce resources efficiently. In their multi-objective model, they considered a multi-modal transportation system for transporting the commodities and evacuees as well. The objective of this model is to minimize the total weighted unserved injured people, total weighted unsatisfied demands, and the number of vehicles where the uncertain elements are the demand of the commodity, number of injured people, and supply of the commodity. On the other side, Fereiduni and Shahanaghi [92] considered the disrup- 
tion scenario (distribution infrastructure bridges) along with the parameter uncertainty, namely, the operational cost of relief centers, unit transportation cost, rescue operation time, and demand of affected areas. Initially, the authors considered a single-objective optimization model to make a decision about the location of facilities, allocation of resources, and evacuation of people for multiple disaster periods. To generate different scenarios, a Monte Carlo simulation is used and afterward, the p-robust approach is used to predict the damages along pathways and facilities. Haghi, Fatemi Ghomi, and Jolai [93] proposed a multi-objective model to distribute the commodities and transport the casualties. To make the model realistic, the authors considered some uncertainties and, to handle the uncertainties, a robust optimization approach was utilized and, finally, the $\varepsilon$-constraint method was used to solve the model. Another multi-objective robust optimization model was proposed by Vahdani, B., Veysmoradi, D., Noori, F., and Mansour, F. [94]. Between the two phases of their proposed model, in the first phase, the establishment of the distribution center and warehouse, as well as the storing of relief goods, was considered and, in the second phase, the distribution of relief goods to the affected areas was considered. Two meta-heuristic algorithms of NSGA-II and MOPSO were used to solve the model. Zheng and Ling [95] proposed a multi-objective fuzzy optimization model for emergency transportation planning where uncertainty is tackled by fuzzy theory. Sarma et al. in [96] used the neutrosophic concept to minimize the cost and time of the redistribution of resources during disaster management.

\subsection{Mass Evacuation}

This area of study can be divided into two groups-the evacuation model for rural areas; evacuation model for the urban areas. The rural area evacuation model is further divided into two categories- the transport system run by the government and the transport system run privately. In the public transport evacuation model, evacuee pickup points, depots, and a shelter for evacuees are optimized along with bus routes, while in the private transport evacuation model, traffic flow management is more highly prioritized. Evacuation models related to the urban area have different characteristics. In urban areas, because of the high density of population traffic congestion, route capacity, flow conservation, lane reversal, etc., are optimized. In the following sections, we review relevant public and private transport evacuation models and urban area evacuation models according to their specific characteristics and functionality. Table 6 summarizes the mass evacuation models in humanitarian logistics. 
Table 6. Mass evacuation model in humanitarian logistics (HL).

\begin{tabular}{|c|c|c|c|c|c|c|}
\hline Authors & Objective Function & Uncertain Components & Decisions & $\begin{array}{l}\text { Deterministic } \\
\text { Model }\end{array}$ & $\begin{array}{c}\text { Non-Deterministic } \\
\text { Model }\end{array}$ & $\begin{array}{c}\text { Solution } \\
\text { Technique/Approach }\end{array}$ \\
\hline Murray-Tuite et al., (2003) & $\begin{array}{l}\text { Minimize the travel time } \\
\text { and evacuee waiting time }\end{array}$ & - & $\begin{array}{l}\text { Link selection, meeting } \\
\text { place selection of people }\end{array}$ & $\sqrt{ }$ & \multirow{4}{*}{$\sqrt{ }$} & $\begin{array}{l}\text { Traffic simulation } \\
\text { software }\end{array}$ \\
\hline Goerigk et al., (2013) & $\begin{array}{l}\text { Minimize the maximum } \\
\text { travel distance }\end{array}$ & - & $\begin{array}{l}\text { Traveling decision of bus } \\
\text { decision, travel time }\end{array}$ & $\sqrt{ }$ & & Greedy algorithm \\
\hline Goerigk et al., (2014) & $\begin{array}{l}\text { Minimize the total } \\
\text { evacuation time }\end{array}$ & Number of evacuees & & & & CPLEX \\
\hline Margulis et al., (2006) & $\begin{array}{l}\text { Maximize the total } \\
\text { evacuated number of people }\end{array}$ & - & Bus trip selection & $\sqrt{ }$ & & \\
\hline Swamy et al., (2017) & $\begin{array}{l}\text { Minimize the total distance } \\
\text { between the pickup } \\
\text { locations and shelters }\end{array}$ & - & $\begin{array}{l}\text { Evacuee pickup point } \\
\text { selection }\end{array}$ & $\sqrt{ }$ & & $\begin{array}{l}\text { Python } 2.7 \text { for } \\
\text { simulation code } \\
\text { generation and } \\
\text { optimization solver } \\
\text { Gurobi } 6.5\end{array}$ \\
\hline Bish et al., (2011) & $\begin{array}{l}\text { Minimize the evacuation } \\
\text { time and total cost }\end{array}$ & - & $\begin{array}{l}\text { Number of evacuees, } \\
\text { bus trip selection }\end{array}$ & $\sqrt{ }$ & & Two heuristic algorithms \\
\hline Ashish et al., (2014) & $\begin{array}{l}\text { Minimize the total } \\
\text { evacuation time }\end{array}$ & $\begin{array}{c}\text { Number of } \\
\text { transit-dependent } \\
\text { evacuees }\end{array}$ & $\begin{array}{l}\text { Trip number of bus, pick } \\
\text { up the point of evacuees, } \\
\text { allocation of bus }\end{array}$ & & $\sqrt{ }$ & GAMS/CPLEX \\
\hline Song et al., (2009) & $\begin{array}{l}\text { Minimize the total } \\
\text { evacuation time }\end{array}$ & Number of evacuees & $\begin{array}{l}\text { Shelter selection, } \\
\text { vehicles' travel }\end{array}$ & & $\sqrt{ }$ & $\begin{array}{l}\text { Hybrid GA, artificial } \\
\text { neural network, hill } \\
\text { climbing heuristic } \\
\text { algorithms }\end{array}$ \\
\hline Liu et al., (2006) & $\begin{array}{l}\text { Maximize the total number } \\
\text { of vehicles entering all } \\
\text { destinations, minimize the } \\
\text { total trip time (including the } \\
\text { waiting time of evacuees) }\end{array}$ & - & Number of vehicles & $\sqrt{ }$ & \multirow{4}{*}{$\sqrt{ }$} & \multirow[b]{2}{*}{$\begin{array}{c}\text { Relaxation-based } \\
\text { heuristic, K-shortest patl }\end{array}$} \\
\hline Wang et al., (2016) & $\begin{array}{l}\text { Minimize the total } \\
\text { evacuation times }\end{array}$ & $\begin{array}{l}\text { Link travel times and } \\
\text { link capacities }\end{array}$ & & & & \\
\hline Kongsomsaksakul et al., (2005) & $\begin{array}{l}\text { Minimize the total travel } \\
\text { time for all evacuees to safe } \\
\text { shelters }\end{array}$ & - & Safe shelter selection & $\sqrt{ }$ & & Genetic algorithm \\
\hline Sayyady et al., (2010) & $\begin{array}{l}\text { Minimize the total } \\
\text { evacuation time and number } \\
\text { of casualties }\end{array}$ & - & Flow of evacuees & $\sqrt{ }$ & & $\begin{array}{l}\text { Traffic simulation } \\
\text { package, CPLEX }\end{array}$ \\
\hline
\end{tabular}


Table 6. Cont

\begin{tabular}{|c|c|c|c|c|c|c|}
\hline Authors & Objective Function & Uncertain Components & Decisions & $\begin{array}{l}\text { Deterministic } \\
\text { Model }\end{array}$ & $\begin{array}{c}\text { Non-Deterministic } \\
\text { Model }\end{array}$ & $\begin{array}{c}\text { Solution } \\
\text { Technique/Approach }\end{array}$ \\
\hline Bretschneider et al., (2011) & $\begin{array}{l}\text { Minimize the average } \\
\text { evacuation time }\end{array}$ & - & $\begin{array}{c}\text { Number of the vehicle, } \\
\text { number of lanes }\end{array}$ & $\sqrt{ }$ & & CPLEX \\
\hline Ye et al., (2012) & $\begin{array}{l}\text { Maximizing the coverage } \\
\text { population }\end{array}$ & - & $\begin{array}{l}\text { Number of a single } \\
\text { residential building for } \\
\text { evacuation }\end{array}$ & $\sqrt{ }$ & & $\begin{array}{l}\text { Arc GIS, shortest path } \\
\text { algorithm }\end{array}$ \\
\hline Goerigk et al., (2014) & $\begin{array}{l}\text { Minimize the evacuation } \\
\text { time and number of used } \\
\text { shelters }\end{array}$ & - & $\begin{array}{l}\text { Number of evacuees } \\
\text { using cars and bus }\end{array}$ & $\sqrt{ }$ & & Genetic algorithm \\
\hline Kimms et al., (2018) & $\begin{array}{l}\text { Minimize the total exposed } \\
\text { hazard, minimize the } \\
\text { deviation of cell capacity } \\
\text { utilization }\end{array}$ & - & $\begin{array}{l}\text { Number of the vehicle } \\
\text { for starting the } \\
\text { evacuation, number of } \\
\text { vehicles used between } \\
\text { two cells }\end{array}$ & $\sqrt{ }$ & & $\begin{array}{l}\text { Path generation } \\
\text { algorithm }\end{array}$ \\
\hline Li Wang (2020) & $\begin{array}{l}\text { Minimize the evacuation } \\
\text { time }\end{array}$ & $\begin{array}{l}\text { Travel time and link } \\
\text { capacity }\end{array}$ & $\begin{array}{l}\text { Flow of people in a } \\
\text { specific link }\end{array}$ & & $\sqrt{ }$ & $\begin{array}{l}\text { Lagrangian } \\
\text { relaxation-based } \\
\text { algorithm }\end{array}$ \\
\hline
\end{tabular}




\subsubsection{Public and Private Transport Evacuation Model}

The transportation system, which is run by the government, can be named as bus evacuation model, and most of the model in the mass evacuation domain is a bus evacuation model. Murray-Tuite and Mahmassani [97] studied household members' behavior at the time of evacuation. For example, it is an innate behavior of household members to seek each other out to evacuate as a single unit; they try to find relatives to evacuate the area. The authors studied this behavior of the people and point out that this behavior will lead the people towards the danger instead of away from it and this behavior leads to longer than expected evacuation time. They formulated a capacitated vehicle routing model aiming to minimize the travel time including evacuee waiting time. Further, Goerigk, Grün, and Heßler [98] presented a bus evacuation problem as a vehicle routing problem. The objective of their model is to minimize the maximum total travel distance. Another study of Goerigk and Grün [99] is to consider the evacuees' number as an uncertain element to make their bus evacuation model more robust and applied a scenario based approach to tackle the uncertainty. The authors considered the simplified version of the bus evacuation problem, which is a vehicle scheduling problem that aims to minimize the total time to evacuate the evacuees. For hurricane evacuation planning, Swamy and Margulis $[100,101]$ used the public transport system in the model. Margulis proposed a decision support system that will help decision-makers with decisions about maximizing the number of evacuated people. Their model can decide on the number of the trip of the bus between pickup points and shelter points in the evacuation process. On the other hand, Swamy provides a mass evacuation strategy before striking the hurricane. In their multi-stage approaches, the first stage is about the determination of pickup locations, assigning the busses to the shelters, and the generation of routes for the pickup and shelter points. The second stage is about assigning the trip number for each route. For example, the route with higher demand requires more trips and lower demand requires fewer trips. Bish [102] provides a mixed-integer programming formulation for the bus evacuation problem. They tried to provide the difference between the classical vehicle routing problem and the bus evacuation problem. The objective of their mixed-integer programming model for the bus evacuation problem is to minimize the duration of the evacuation. Song, He and Zhang [103] present a location-routing model for the people who do not own a car and who are entirely dependent on public transport. Thus, they need to go to the transit point to be evacuated. The number of evacuees is considered to be an uncertain number. The authors introduced the chance constraint method for demand uncertainty and a stochastic number of evacuees. Another transit-based evacuation model under demand uncertainty is proposed by Ashish, Yingyan, and Yafeng [104]. To determine the optimal pickup points for evacuees and allocate the available buses to transport the evacuees, the authors proposed a robust optimization model aiming to minimize the total evacuation time. Liu, Lai, and Chang [105] presented a simulation-based two-level integrated optimization system where the higher level maximizes the throughput during evacuation time and the lower level minimizes the total travel time as well as the waiting time of evacuees. The authors used a cell transmission concept to show the relationship of traffic flow with mathematical formulations. Another cell transmission model based on evacuation planning is proposed by Chiu and Zheng [106]. They considered the multi-priority groups where some groups have more priority over others. Their cell transmission-based linear-programming model helps to make the decision on departure schedule, traffic assignment, and mobilization destination. L. Wang [107] considered the stochastic link travel times and capacity in their proposed traffic routing problem for disaster response. To guarantee the traveling efficiency and to reduce the congestion, they considered the capacity of each link where the number of agents on a specific link is considered limited over different scenarios. To solve their model, they proposed a heuristic algorithm which is the combination of the Lagrangian relaxation-based approach and the k-shortest path technique. 


\subsubsection{Urban Area Evacuation Model}

Concerning the urban area evacuation model, a shelter location-allocation model is formulated by Kongsomsaksakul, Chen, and Yang [26] for flood evacuation planning. In their bi-level programming model, the upper level is a location problem where the authority will decide on the location, but at the lower level, evacuees will take a decision. The upper and lower-level decisions are modeled according to game theory and, finally, a genetic algorithm is used to solve the model. To find optimal evacuation routes for transit-dependent citizens during no-notice disasters, a mixed-integer linear programming model is proposed by Sayyady and Eksioglu [108]. The objective of this model is to minimize the total evacuation time and the number of casualties. Bretschneider and Kimms [109] developed a mixed-integer mathematical model for fast and safe evacuation planning in the case of disasters such as floods, hurricanes, and chemical accidents. Their proposed model provides a reorganization of the traffic routing of a certain area. Their dynamic network flow problem minimizes the evacuation time while prohibiting conflicts within intersections. Spatial analysis techniques of Geographical Information System (GIS) are employed by Ye, M. [110] for urban area evacuation planning in case of an earthquake. Their methodology encompasses three aspects: the distribution analysis of emergency evacuation demands, the shelter space accessibility calculation, and the evacuation destinations optimization. Goerigk, Deghdak, and Heßler [111] proposed a macroscopic multi-criteria optimization model for evacuation planning under different scenarios and they named their model the Comprehensive Evacuation Problem (CEP). Their objective is to minimize the evacuation time, the risk, and the number of used shelters (safe places, e.g., stadiums or gymnasiums). As their proposed CEP is a non-deterministic polynomial-time hardness (NP hard) model, a genetic algorithm is established as a method of choice for large-scale multicriteria problems. Kimms and Maiwald [112] presented a biobjective-path-based evacuation model based on the assumption of the Cell-Transmission Model. They tried to minimize the overall hazard under some restrictions (e.g., rescuing all evacuees) and introduced the aspect of resilience in the context of evacuation planning. As they modeled two conflicting objective functions, the authors dealt with these objective functions by applying the $\varepsilon$-constraint method. As it is tough to predict the condition of traffic after the disaster, Li Wang [113] considered the travel time and capacity of the road as an uncertain element and proposed a two-stage stochastic programming model to evacuate the urban people. Apart from the mass evacuation model and rural area evacuation model, an interesting study is conducted by Goniewicz Krzysztof, Patrycja Misztal-Okonska, and Witold Pawłowski [114] where authors analyzed the requirements of a safe evacuation plan for the patients in the hospital and they observed an obligation of polish law in the case of safe evacuation.

\section{Future Research Direction}

A rigorous review of selected articles indicates that most of the focus on HL is on the preparedness and response phase considering facility location, relief distribution, and mass evacuation. After exploring the current research trend, an effort has been paid to the direction of future research according to the four phases of the disaster life cycle. The lowest concentrated phase among the four phases of the disaster life cycle is the mitigation and recovery phase. In the mitigation phase, a reallocation strategy can be an area for facility location problems where the researcher should focus more. Reallocation of inhabitants to the safest place from the disastrous areas is very important for minimizing the vulnerability of people.

As ensuring the safety of the inhabitants is an important and long-term planning issue, the mathematical model for safety planning should be robust. In the preparation stage, even though there is some research where researchers investigated the optimum location of shelters, permanent distribution centers, and permanent medical centers location, there is not enough study on the long-term planning and preparation to decide the location of the warehouse. Countries such as China, Indonesia, Japan, the Philippines, and the USA 
are disaster-prone and, therefore, these countries should have optimum planning for the selection of national emergency warehouse locations [38].

The allocation of resources is not widely studied in both response and preparedness stages. There are some studies for single-period allocation, but multi-period allocation is seldomly seen. The relief distribution network consists of distribution centers and demand points and the capacity of the distribution centers is limited but the demand for relief is an uncertain parameter. As a result, the transfer of relief items between facilities or inter-facility stock can be studied for the efficient allocation of resources. If the assigned distribution center cannot meet the demand, then distribution centers are charged with dissatisfaction costs. However, for the farther period's demand, if the distribution center can be assigned, the probability of demand satisfaction would be higher. This is caused by the lack of multi-period and inter-facility stock transfer consideration. Recently, some authors have used multi-period analysis in their model, but still, this is not enough. For further studies in the preparation and response stage, the inclusion of the multi-period model is an important aspect.

Response for the disaster-relief operation does not always work according to the pre-planning. Response operations that have been running for a long time after a major disaster sometimes may face fuel shortage and an inadequate number of vehicles. In addition, some disasters are responsible for the debris in the road and block the roadways that can cause trouble in the response of disaster-relief operations. Eventually, this kind of situation increases lead time. Due to increased lead time, some distribution centers may have an excessive inventory of relief goods and some may have a scarcity of relief goods. To replenish the scarce distribution center, a redistribution strategy of relief goods among distribution centers and demand points can become handy. Another important issue in such a case is the short life of relief goods. Due to the short life, with the passage of time, these relief goods will decay. In the present literature, the study of short life relief goods in the response stage of $\mathrm{HL}$ is missing.

Additionally, in the response stage, there are some published works where authors consider the temporary distribution center and medical center establishment for relief distribution and causality transportation operation, but the consideration of uncertainty and employing a robust model is missing. In addition, obnoxious facility location problems have not been studied widely. Another topic that has not been studied intensively in the response stage is inventory planning. The study of inventory for both warehouse and distribution centers is an important sector for efficient distribution of relief. The uncertainty associated with demand and supply in HL is higher than the uncertainty in the commercial supply chain and logistics. As a result of that, consideration of inventory decisions in relief allocation and distribution models is seldom seen. In such a case, stochastic programming and robust optimization model can be used to respond to the real situation (e.g., consideration of uncertainty).

In the response phase, the causality transportation is also limited and can be furthered by combining with uncertain parameters. The injury level of patients, transportation time, and the demand for medical kits can be considered as probabilistic parameters. Disruption events can also be included. This may include damage to facilities, stock, and other resources. Sometimes redistribution planning of medical kits can help to minimize the demand for a particular treatment center. In the post-disaster phase, the crew scheduling of debris collection is an important part of disaster management. Research on debris collection is lacking. On the other hand, many parties want to work together in the response phase of the disaster. Thus, manpower management is a challenging part too.

The combination of different phases of the disaster life cycle is an unavoidable field to study. In most cases, a single phase is dealt with to conduct the study. Moreover, three major areas of HL (facility location, relief distribution, and evacuation) also should be combined; even though in recent years there has been an effort to combine them, more focus is needed. In this effort to combine the areas, the problem becomes complex to solve, over and above the probabilistic nature of the parameters making them more complex. To deal 
with the probabilistic nature, most of the researchers are using stochastic programming and robust optimization approaches. There are other approaches such as fuzzy programming, fuzzy set theory, neutrosophic approach, and others to hedge against the probabilistic nature of the model, and the solution obtained by different approaches can be compared for the effectiveness of the model.

One of the challenges in the optimization model is having adequate data. In large-scale disasters, data may not be available or may not be easily readable. Even if data are available sometimes, it takes a long time to solve the model. In disaster situations, having the desired result from the optimization model in a short time is very crucial. Therefore, directives are needed urgently in an emergency and, thus, improvements in solution algorithms are very essential. Appropriate algorithms can help decision-makers to make decisions in a short time.

\section{Conclusions}

This research aims to address the current research trend of HL, especially the optimization problem used to achieve the different objectives of core sectors of $\mathrm{HL}$, and to provide the future research direction. The three main sectors where decision-makers should emphasize before and after the disaster for avoiding the devastation of disaster and vulnerability of affected people are facility location problem, relief distribution, and mass evacuation. An effort has been given for further classification of those three main sectors into deterministic and non-deterministic models as well. In the case of facility location problems, all the variants of the facility location problem are studied and, in the table of the deterministic model's constraints, decision variables, model type, and solution procedures are included.

It can be noted from the reviewed article that the response stage of the disaster receives the highest priority, and emphasis on the preparation stage has a lower priority. However, the mitigation and recovery stages receive the lowest attention from the researchers. The integration of two different stages of disaster is an important sector to explore also. Another important observation is the development and exertion of different models to hedge against the uncertain parameters. The uncertain elements and the model used so far to tackle the uncertainty is also presented in the tables.

The limitation of this literature review study is that it considers only the mathematical model. Secondly, research articles published before 2004 are not included in this study. In non-deterministic models, this study mostly covered the stochastic programming approach and robust optimization. There are other approaches such as fuzzy set theory, neutrosophic sets, and others that are overlooked in this study.

Finally, it can be concluded that this study can be useful for the researchers to understand the current trend of the optimization problem in HL and the modeling techniques. Researchers can find out the research gap easily and contribute to society through their research.

Author Contributions: Conceptualization, M.k.N., and I.M.H.; methodology, M.k.N., and I.M.H.; software, M.k.N.; validation, M.k.N., and I.M.H.; formal analysis, M.k.N.; investigation, M.k.N., and I.M.H.; resources, M.k.N.; data curation, I.M.H.; writing-original draft preparation, M.k.N.; writing-review and editing, I.M.H.; visualization, M.k.N., and I.M.H.; supervision, I.M.H.; project administration, I.M.H.; funding acquisition, I.M.H. All authors have read and agreed to the published version of the manuscript.

Funding: The authors extend their appreciation to the Deputyship for Research and Innovation, "Ministry of Education" in Saudi Arabia for funding this research work through the project number IFKSURP-71.

Data Availability Statement: Not applicable.

Acknowledgments: We would like to thank the Editors of the journal as well as the anonymous reviewers for their valuable suggestions that make the paper stronger and more consistent.

Conflicts of Interest: The authors declare no conflict of interest. 


\section{References}

1. Guha-Sapir, D.; Vos, F.; Below, R.; Ponserre, S. Annual Disaster Statistical Review 2016, The Numbers and Trends; Centre for Research on the Epidemiology of Disasters (CRED): Brussels, Belgium, 2016; pp. 1-91.

2. Bealt, J.; Mansouri, S.A. From disaster to development: A systematic review of community-driven humanitarian logistics. Disasters 2018, 42, 124-148. [CrossRef] [PubMed]

3. Habib, M.S.; Lee, Y.H.; Memon, M.S. Mathematical Models in Humanitarian Supply Chain Management: A Systematic Literature Review. Math. Probl. Eng. 2016, 2016, 3212095. [CrossRef]

4. Tupper, A.; Carn, S.; Davey, J.; Kamada, Y.; Potts, R.; Prata, F.; Tokuno, M. An evaluation of volcanic cloud detection techniques during recent significant eruptions in the western 'Ring of Fire'. Remote Sens. Environ. 2004, 91, 27-46. [CrossRef]

5. Thomas, A.; Kopczak, L. From Logistics to Supply Chain Management: The Path Forward in the Humanitarian Sector; Fritz Institute: San Francisco, CA, USA, 2005.

6. Altay, N.; Green, W.G. OR/MS research in disaster operations management. Eur. J. Oper. Res. 2006, 175, 475-493. [CrossRef]

7. Natarajarathinam, M.; Capar, I.; Narayanan, A. Managing Supply Chains in Times of Crisis: A Review of Literature and Insights. Int. J. Phys. Distrib. Logist. Manag. 2009, 39. [CrossRef]

8. Simpson, N.C.; Hancock, P.G. Fifty years of operational research and emergency response. J. Oper. Res. Soc. 2009, 60 (Suppl. 1), 26-139. [CrossRef]

9. Caunhye, A.M.; Nie, X.; Pokharel, S. Optimization models in emergency logistics: A literature review. Socioecon. Plann. Sci. 2012, 46, 4-13. [CrossRef]

10. Leiras, A.; de Brito, I.; Peres, E.Q.; Bertazzo, T.R.; Yoshizaki, H.T.Y. Literature review of humanitarian logistics research: Trends and challenges. J. Humanit. Logist. Supply Chain Manag. 2014, 4, 95-130. [CrossRef]

11. Boonmee, C.; Arimura, M.; Asada, T. Facility location optimization model for emergency humanitarian logistics. Int. J. Disaster Risk Reduct. 2017, 24, 485-498. [CrossRef]

12. Anaya-Arenas, A.M.; Renaud, J.; Ruiz, A. Relief Distribution Networks: A Systematic Review. Ann. Oper. Res. 2014, 223, 53-79. [CrossRef]

13. Burkle, F.M.; Bradt, D.A.; Ryan, B.J. Global Public Health Database Support to Population-Based Management of Pandemics and Global Public Health Crises, Part I: The Concept. Prehosp Disaster Med. 2020, 1-10. [CrossRef] [PubMed]

14. Goldschmidt, K.H.; Kumar, S. Humanitarian operations and crisis/disaster management: A retrospective review of the literature and framework for development. Int. J. Disaster Risk Reduct. 2016, 20, 1-13. [CrossRef]

15. Tranfield, D.; Denyer, D.; Smart, P. Towards a Methodology for Developing Evidence-Informed Management Knowledge by Means of Systematic Review. Br. J. Manag. 2003, 14, 207-222. [CrossRef]

16. Arabani, A.B.; Farahani, R.Z. Facility location dynamics: An overview of classifications and applications. Comput. Ind. Eng. 2012, 62, 408-420. [CrossRef]

17. Jia, H.; Ordóñez, F.; Dessouky, M. A modeling framework for facility location of medical services for large-scale emergencies. IIE Trans. 2007, 39, 41-55. [CrossRef]

18. Jia, H.; Ordóñez, F.; Dessouky, M.M. Solution approaches for facility location of medical supplies for large-scale emergencies. Comput. Ind. Eng. 2007, 52, 257-276. [CrossRef]

19. Hu, S.L.; Han, C.F.; Meng, L.P. Stochastic optimization for joint decision making of inventory and procurement in humanitarian relief. Comput. Ind. Eng. 2017, 111, 39-49. [CrossRef]

20. ReVelle, C.S.; Eiselt, H.A.; Daskin, M.S. A bibliography for some fundamental problem categories in discrete location science. Eur. J. Oper. Res. 2008, 184, 817-848. [CrossRef]

21. ReVelle, C.S.; Swain, W.R. Central facilieits location. Geogr. Anal. 1970, 2, 30-42. [CrossRef]

22. McCall, V.M. Designing and Pre-Positioning Humanitarian Assistance Pack-Up Kits (HA PUKs) to Support Pacific Fleet Emergency Relief Operations; Naval Postgraduate School: Monterey, CA, USA, 2006.

23. Lin, Y.-H.; Batta, R.; Rogerson, P.A.; Blatt, A.; Flanigan, M. Location of temporary depots to facilitate relief operations after an earthquake. Socioecon. Plann. Sci. 2012, 46, 112-123. [CrossRef]

24. Flanigan, M.; Blatt, A.; Batta, R.; Lin, Y.-H.; Rogerson, P.A. A logistics model for emergency supply of critical items in the aftermath of a disaster. Socioecon. Plann. Sci. 2011, 45, 132-145.

25. Abounacer, R.; Rekik, M.; Renaud, J. An exact solution approach for multi-objective location-transportation problem for disaster response. Comput. Oper. Res. 2014, 41, 83-93. [CrossRef]

26. Kongsomsaksakul, S.; Chen, A.; Yang, C. Shelter Location-Allocation Model for Flood Evacuation Planning. J. East. Asia Soc. Transp. Stud. 2005, 6, 4237-4252.

27. Toregas, C.; Swain, R.; ReVelle, C.; Bergman, L. The Location of Emergency Service Facilities. Oper. Res. 1971, 19, 1363-1373. [CrossRef]

28. Dekle, J.; Lavieri, M.S.; Martin, E.; Emir-Farinas, H.; Francis, R.L. A florida county locates disaster recovery centers. Interfaces 2005, 35, 133-139. [CrossRef]

29. Rath, S.; Gutjahr, W.J. A math-heuristic for the warehouse location-routing problem in disaster relief. Comput. Oper. Res. 2014, 42, 25-39. [CrossRef]

30. Hu, F.; Yang, S.; Xu, W. A non-dominated sorting genetic algorithm for the location and districting planning of earthquake shelters. Int. J. Geogr. Inf. Sci. 2014, 28, 1482-1501. [CrossRef] 
31. Xu, J.; Yin, X.; Chen, D.; An, J.; Nie, G. Multi-criteria location model of earthquake evacuation shelters to aid in urban planning. Int. J. Disaster Risk Reduct. 2016, 20, 51-62. [CrossRef]

32. Church, R.; ReVelle, C. The maximal covering location problem. Pap. Reg. Sci. Assoc. 1974, 32, 101-118. [CrossRef]

33. Balcik, B.; Beamon, B.M. Facility location in humanitarian relief. Int. J. Logist. 2008, 11, 101-121. [CrossRef]

34. Barzinpour, F.; Esmaeili, V. A multi-objective relief chain location distribution model for urban disaster management. Int. J. Adv. Manuf. Technol. 2014, 70, 1291-1302. [CrossRef]

35. Das, R. Disaster preparedness for better response: Logistics perspectives. Int. J. Disaster Risk Reduct. 2018, 31, 153-159. [CrossRef]

36. Daskin, M.S. Network and Discrete Location: Models, Algorithms, and Applications, 1st ed.; John Wiley \& Sons: Chichester, UK, 2013.

37. Hakimi, S.L. Optimum Locations of Switching Centers and the Absolute Centers and Medians of a Graph. Oper. Res. 1964, 12, 450-459. [CrossRef]

38. Ye, F.; Zhao, Q.; Xi, M.; Dessouky, M. Chinese national emergency warehouse location research based on VNS algorithm. Electron. Notes Discret. Math. 2015, 47,61-68. [CrossRef]

39. Khayal, D.; Pradhananga, R.; Pokharel, S.; Mutlu, F. A model for planning locations of temporary distribution facilities for emergency response. Socioecon. Plann. Sci. 2015, 52, 22-30. [CrossRef]

40. Chen, A.Y.; Yu, T.Y. Network based temporary facility location for the Emergency Medical Services considering the disaster induced demand and the transportation infrastructure in disaster response. Transp. Res. Part B Methodol. 2016, 91, 408-423. [CrossRef]

41. Cotes, N.; Cantillo, V. Including deprivation costs in facility location models for humanitarian relief logistics. Socioecon. Plann. Sci. 2019, 65, 89-100. [CrossRef]

42. Pérez-Galarce, F.; Canales, L.J.; Vergara, C.; Candia-Véjar, A. An optimization model for the location of disaster refuges. Socioecon. Plann. Sci. 2017, 59, 56-66. [CrossRef]

43. Akbari-Jafarabadi, M.; Tavakkoli-Moghaddam, R.; Mahmoodjanloo, M.; Rahimi, Y. A tri-level r-interdiction median model for a facility location problem under imminent attack. Comput. Ind. Eng. 2017, 114, 151-165. [CrossRef]

44. Church, R.L.; Scaparra, M.P.; Middleton, R.S. Identifying Critical Infrastructure: The Median and Covering Facility Interdiction Problems. Ann. Assoc. Am. Geogr. 2004, 94, 491-502. [CrossRef]

45. Chang, M.S.; Tseng, Y.L.; Chen, J.W. A scenario planning approach for the flood emergency logistics preparation problem under uncertainty. Transp. Res. Part E Logist. Transp. Rev. 2007, 43, 737-754. [CrossRef]

46. Rawls, C.G.; Turnquist, M.A. Pre-positioning of emergency supplies for disaster response. Transp. Res. Part B Methodol. 2010, 44, 521-534. [CrossRef]

47. Oksuz, M.K.; Satoglu, S.I. A two-stage stochastic model for location planning of temporary medical centers for disaster response. Int. J. Disaster Risk Reduct. 2020, 44, 101426. [CrossRef]

48. Rawls, C.G.; Turnquist, M.A. Pre-positioning and dynamic delivery planning for short-term response following a natural disaster. Socioecon. Plann. Sci. 2012, 46, 46-54. [CrossRef]

49. Monzón, J.; Liberatore, F. A Mathematical Pre-Disaster Model with Uncertainty and Multiple Criteria for Facility Location and Network Fortification. Mathematics 2020, 8, 529. [CrossRef]

50. Hong, X.; Lejeune, M.A.; Noyan, N. Stochastic network design for disaster preparedness. IIE Trans. Institute Ind. Eng. 2015, 47, 329-357. [CrossRef]

51. Bozorgi-Amiri, A.; Khorsi, M. A dynamic multi-objective location-routing model for relief logistic planning under uncertainty on demand, travel time, and cost parameters. Int. J. Adv. Manuf. Technol. 2016, 85, 1633-1648. [CrossRef]

52. Moreno, A.; Alem, D.; Ferreira, D.; Clark, A. An effective two-stage stochastic multi-trip location-transportation model with social concerns in relief supply chains. Eur. J. Oper. Res. 2018, 269, 1050-1071. [CrossRef]

53. An, S.; Cui, N.; Bai, Y.; Xie, W.; Chen, M.; Ouyang, Y. Reliable emergency service facility location under facility disruption, en-route congestion and in-facility queuing. Transp. Res. Part E Logist. Transp. Rev. 2015, 82, 199-216. [CrossRef]

54. Mulvey, J.M.; Vanderbei, R.J.; Zenios, S.A. Robust Optimization of Large-Scale Systems. Oper. Res. 1995, 43, 264-281. [CrossRef]

55. Bertsimas, D.; Sim, M. The Price of Robustness. Oper. Res. 2004, 52, 35-53. [CrossRef]

56. Rezaei-Malek, M.; Tavakkoli-Moghaddam, R.; Zahiri, B.; Bozorgi-Amiri, A. An interactive approach for designing a robust disaster relief logistics network with perishable commodities. Comput. Ind. Eng. 2016, 94, 201-215. [CrossRef]

57. Reeves, G.R.; MacLeod, K.R. Some experiments in Tchebycheff-based approaches for interactive multiple objective decision making. Comput. Oper. Res. 1999, 26, 1311-1321. [CrossRef]

58. Muggy, L.; Stamm, J.L.H. Dynamic, robust models to quantify the impact of decentralization in post-disaster health care facility location decisions. Oper. Res. Heal. Care 2017, 12, 43-59. [CrossRef]

59. Ni, W.; Shu, J.; Song, M. Location and Emergency Inventory Pre-Positioning for Disaster Response Operations: Min-Max Robust Model and a Case Study of Yushu Earthquake. Prod. Oper. Manag. 2018, 27, 160-183. [CrossRef]

60. Mohammadi, S.; Avakh, S.; Vahdani, B.; Alinezhad, A. Computers \& Industrial Engineering A robust neutrosophic fuzzy-based approach to integrate reliable facility location and routing decisions for disaster relief under fairness and aftershocks concerns. Comput. Ind. Eng. 2020, 148, 106734.

61. Yahyaei, M.; Bozorgi-Amiri, A. Robust reliable humanitarian relief network design: An integration of shelter and supply facility location. Ann. Oper. Res. 2018, 283, 897-916. [CrossRef] 
62. Jenkins, P.R.; Lunday, B.J.; Robbins, M.J. Robust, multi-objective optimization for the military medical evacuation locationallocation problem. Omega 2019, 97, 1-12. [CrossRef]

63. Gao, X.; Nayeem, M.K.; Hezam, I.M. A robust two-stage transit-based evacuation model for large-scale disaster response. Meas. J. Int. Meas. Confed. 2019, 145, 713-723. [CrossRef]

64. Renkli, Ç.; Duran, S. Pre-Positioning Disaster Response Facilities and Relief Items. Hum. Ecol. Risk Assess 2015, 21, 1169-1185. [CrossRef]

65. Kınay, Ö.B.; Kara, B.Y.; Saldanha-da-Gama, F.; Correia, I. Modeling the shelter site location problem using chance constraints: A case study for Istanbul. Eur. J. Oper. Res. 2018, 270, 132-145. [CrossRef]

66. Afshar, A.; Haghani, A. Modeling integrated supply chain logistics in real-time large-scale disaster relief operations. Socioecon. Plann. Sci. 2012, 46, 327-338. [CrossRef]

67. Wang, H.; Du, L.; Ma, S. Multi-objective open location-routing model with split delivery for optimized relief distribution in post-earthquake. Transp. Res. Part E Logist. Transp. Rev. 2014, 69, 160-179. [CrossRef]

68. Yi, W.; Kumar, A. Ant colony optimization for disaster relief operations. Transp. Res. Part E Logist. Transp. Rev. 2007, 43, 660-672. [CrossRef]

69. Özdamar, L.; Ekinci, E.; Küçükyazici, B. Emergency logistics planning in natural disasters. Ann. Oper. Res. 2004, 129, 217-245. [CrossRef]

70. Campbell, A.M.; Vandenbussche, D.; Hermann, W. Routing for Relief Efforts. Transp. Sci. 2008, 42, 127-145. [CrossRef]

71. Al Theeb, N.; Murray, C. Vehicle routing and resource distribution in postdisaster humanitarian relief operations. Int. Trans. Oper. Res. 2017, 24, 1253-1284. [CrossRef]

72. Balcik, B.; Beamon, B.M.; Smilowitz, K. Last mile distribution in humanitarian relief. J. Intell. Transp. Syst. Technol. Plann. Oper. 2008, 12, 51-63. [CrossRef]

73. Rabta, B.; Wankmüller, C.; Reiner, G. A drone fleet model for last-mile distribution in disaster relief operations. Int. J. Disaster Risk Reduct. 2018, 28, 107-112. [CrossRef]

74. Horner, M.W.; Downs, J.A. Optimizing hurricane disaster relief goods distribution: Model development and application with respect to planning strategies. Disasters 2010, 34, 821-844. [CrossRef]

75. Tzeng, G.H.; Cheng, H.J.; Huang, T.D. Multi-objective optimal planning for designing relief delivery systems. Transp. Res. Part E Logist. Transp. Rev. 2007, 43, 673-686. [CrossRef]

76. Vitoriano, B.; Ortuño, M.T.; Tirado, G.; Montero, J. A multi-criteria optimization model for humanitarian aid distribution. J. Glob. Optim. 2011, 51, 189-208. [CrossRef]

77. Pradhananga, R.; Mutlu, F.; Pokharel, S.; Holguín-Veras, J.; Seth, D. An integrated resource allocation and distribution model for pre-disaster planning. Comput. Ind. Eng. 2016, 91, 229-238. [CrossRef]

78. Lu, C.C.; Ying, K.C.; Chen, H.J. Real-time relief distribution in the aftermath of disasters-A rolling horizon approach. Transp. Res. Part E Logist. Transp. Rev. 2016, 93, 1-20. [CrossRef]

79. Li, L.; Jin, M.; Zhang, L. Sheltering network planning and management with a case in the Gulf Coast region. Int. J. Prod. Econ. 2011, 131, 431-440. [CrossRef]

80. Noyan, N.; Balcik, B.; Atakan, S. A Stochastic Optimization Model for Designing Last Mile Relief Networks. Transp. Sci. 2016, 50, 1092-1113. [CrossRef]

81. Tofighi, S.; Torabi, S.A.; Mansouri, S.A. Humanitarian logistics network design under mixed uncertainty. Eur. J. Oper. Res. 2016, 250, 239-250. [CrossRef]

82. Alem, D.; Clark, A.; Moreno, A. Stochastic network models for logistics planning in disaster relief. Eur. J. Oper. Res. 2016, 255, 187-206. [CrossRef]

83. Salmero, J. Stochastic Optimization for Natural Disaster Asset Prepositioning. Prod. Oper. Manag. 2010, 19, 561-574. [CrossRef]

84. Barbarosoğlu, G.; Arda, Y. A two-stage stochastic programming framework for transportation planning in disaster response. J. Oper. Res. Soc. 2004, 55, 43-53. [CrossRef]

85. Döyen, A.; Aras, N.; Barbarosoğlu, G. A two-echelon stochastic facility location model for humanitarian relief logistics. Optim. Lett. 2012, 6, 1123-1145. [CrossRef]

86. Mete, H.O.; Zabinsky, Z.B. Stochastic optimization of medical supply location and distribution in disaster management. Int. J. Prod. Econ. 2010, 126, 76-84. [CrossRef]

87. Moreno, A.; Alem, D.; Ferreira, D. Heuristic approaches for the multiperiod location-transportation problem with reuse of vehicles in emergency logistics. Comput. Oper. Res. 2016, 69, 79-96. [CrossRef]

88. Ahmadi, M.; Seifi, A.; Tootooni, B. A humanitarian logistics model for disaster relief operation considering network failure and standard relief time: A case study on San Francisco district. Transp. Res. Part E Logist. Transp. Rev. 2015, 75, 145-163. [CrossRef]

89. Ghasemi, P.; Khalili-damghani, K.; Hafezalkotob, A.; Raissi, S. Stochastic Optimization Model for Distribution and Evacuation Planning (A Case Study of Tehran Earthquake). Socioecon. Plann. Sci. 2019, 71. [CrossRef]

90. Li, Y.; Yu, G.; Zhang, J. A three-stage stochastic model for emergency relief planning considering secondary disasters. Eng. Optim. 2020, 1-25. [CrossRef]

91. Najafi, M.; Eshghi, K.; Dullaert, W. A multi-objective robust optimization model for logistics planning in the earthquake response phase. Transp. Res. Part E Logist. Transp. Rev. 2013, 49, 217-249. [CrossRef] 
92. Fereiduni, M.; Shahanaghi, K. A robust optimization model for distribution and evacuation in the disaster response phase. J. Ind. Eng. Int. 2016, 13, 117-141. [CrossRef]

93. Haghi, M.; Ghomi, S.M.T.F.; Jolai, F. Developing a robust multi-objective model for pre/post disaster times under uncertainty in demand and resource. J. Clean. Prod. 2017, 154, 188-202. [CrossRef]

94. Vahdani, B.; Veysmoradi, D.; Noori, F.; Mansour, F. Two-stage multi-objective location-routing-inventory model for humanitarian logistics network design under uncertainty. Int. J. Disaster Risk Reduct. 2018, 27, 290-306. [CrossRef]

95. Zheng, Y.J.; Ling, H.F. Emergency transportation planning in disaster relief supply chain management: A cooperative fuzzy optimization approach. Soft Comput. 2013, 17, 1301-1314. [CrossRef]

96. Sarma, D.; Das, A.; Bera, U.K.; Hezam, I.M. Redistribution for cost minimization in disaster management under uncertainty with trapezoidal neutrosophic number. Comput. Ind. 2019, 109, 226-238. [CrossRef]

97. Murray-Tuite, P.M.; Mahmassani, H.S. Model of Household Trip-Chain Sequencing in Emergency Evacuation. Transp. Res. Rec. J. Transp. Res. Board 2003, 1831, 21-29. [CrossRef]

98. Goerigk, M.; Grün, B.; Heßler, P. Branch and bound algorithms for the bus evacuation problem. Comput. Oper. Res. 2013, 40, 3010-3020. [CrossRef]

99. Goerigk, M.; Grün, B. A robust bus evacuation model with delayed scenario information. OR Spectr. 2014, 36, 923-948. [CrossRef]

100. Swamy, R.; Kang, J.E.; Batta, R.; Chung, Y. Hurricane evacuation planning using public transportation. Socioecon. Plann. Sci. 2017, 59, 43-55. [CrossRef]

101. Margulis, L.; Charosky, P.; Fernandez, J.; Centeno, M. Hurricane Evacuation Decision-Support Model for Bus Dispatch. In Proceedings of the Fourth LACCEI International Latin American and Caribbean Conference for Engineering and Technology (LACCET '2006), Mayaguez, Puerto Rico, 21-23 June 2006.

102. Bish, D.R. Planning for a bus-based evacuation. OR Spectr. 2011, 33, 629-654. [CrossRef]

103. Song, R.; He, S.; Zhang, L. Optimum Transit Operations during the Emergency Evacuations. J. Transp. Syst. Eng. Inf. Technol. 2009, 9, 154-160. [CrossRef]

104. Ashish, K.; Lou, Y.; Yin, Y. Pick-up locations and bus allocation for transit-based evacuation planning with demand uncertainty. J. Adv. Transp. 2014, 7, 721-733.

105. Liu, Y.; Lai, X.; Chang, G.-L. Two-Level Integrated Optimization System for Planning of Emergency Evacuation. J. Transp. Eng. 2006, 132, 800-807. [CrossRef]

106. Chiu, Y.C.; Zheng, H. Real-time mobilization decisions for multi-priority emergency response resources and evacuation groups: Model formulation and solution. Transp. Res. Part E Logist. Transp. Rev. 2007, 43, 710-736. [CrossRef]

107. Wang, L.; Yang, L.; Gao, Z.; Li, S.; Zhou, X. Evacuation planning for disaster responses: A stochastic programming framework. Transp. Res. Part C Emerg. Technol. 2016, 69, 150-172. [CrossRef]

108. Sayyady, F.; Eksioglu, S.D. Optimizing the use of public transit system during no-notice evacuation of urban areas. Comput. Ind. Eng. 2010, 59, 488-495. [CrossRef]

109. Bretschneider, S.; Kimms, A. A basic mathematical model for evacuation problems in urban areas. Transp. Res. Part A Policy Pract. 2011, 45, 523-539. [CrossRef]

110. Ye, M.; Wang, J.; Huang, J.; Xu, S.; Chen, Z. Methodology and its application for community-scale evacuation planning against earthquake disaster. Nat. Hazards 2012, 61, 881-892. [CrossRef]

111. Goerigk, M.; Deghdak, K.; Heßler, P. A comprehensive evacuation planning model and genetic solution algorithm. Transp. Res. Part E Logist. Transp. Rev. 2014, 71, 82-97. [CrossRef]

112. Kimms, A.; Maiwald, M. Bi-objective safe and resilient urban evacuation planning. Eur. J. Oper. Res. 2018, $269,1122-1136$. [CrossRef]

113. Wang, L. A two-stage stochastic programming framework for evacuation planning in disaster responses. Comput. Ind. Eng. 2020, 145, 106458. [CrossRef]

114. Goniewicz, K.; Misztal-Okońska, P.; Pawłowski, W.; Burkle, F.M.; Czerski, R.; Hertelendy, A.J.; Goniewicz, M. Evacuation from Healthcare Facilities in Poland: Legal Preparedness and Preparation. Int. J. Environ. Res. Public Health 2020, 17, 1779. [CrossRef] 